Seyahat ve Otel İşletmeciliği Dergisi/

Journal of Travel and Hospitality Management

14 (1), 2017, 108-129.

Gönderim Tarihi:10.03.2016

Kabul Tarihi:13.07.2016

\title{
İş Stresi İle Toksik Davranışlar Arasındaki İlişki: Aşçılar Üzerinde Bir Araştırma*
}

\section{The Relationship Between Job Stress and Toxic Behaviors: A Study On Chefs}

\author{
Doç. Dr. Kamil UNUR \\ Mersin Üniversitesi \\ Turizm Fakültesi \\ E-posta: kunur@yahoo.com
}

\author{
Yrd. Doç.Dr. Yeliz PEKERŞEN \\ Necmettin Erbakan Üniversitesi \\ Turizm Fakültesi \\ E-posta: yeliz.ulusan@gmail.com
}

Öz

Stres, birçok sektörde olduğu gibi turizm sektöründe de çalışanların günlük yaşamlarının bir gerçeği haline gelmiştir. Çalışanlar ve yöneticiler, değişimin ve belirsizliğin hâkim olduğu ortamlarda çalışmaktadırlar. Stres yaratan faktörlerin çoğu yöneticilerin kontrol edemeyecekleri nitelikte olduğundan, yöneticiler ve diğer çalışanlar bu ortama uyum göstermekte zorlanmaktadırlar. Özelikle otellerin mutfak bölümünde çalışan aşçılar çoğu zaman çalışma koşulları bakımından yoğun stres altında görevlerini yerine getirmekte, mutfağın sıcak ve boğucu havası bu bölümde çalışan aşçıları ve mutfak personelini asabileştirmekte ve bunun sonucu olarak da diğer işgörenler ile gereksiz tartışmalara girebilmektedirler. Bu gibi durumlarla karşılaşılması ise aşçıların toksik davranışlarının artmasına sebebiyet verebilmektedir. Çalışmanın amacı otel işletmelerinde çalışan aşçıların iş stresi ile toksik davranışları arasındaki ilişkiyi incelemektir. Bu kapsamda, Türkiye'de faaliyet gösteren beş yıldızlı otel işletmelerinde çalışan 449 aşçıya anket uygulanarak veriler toplanmıştır. Yapılan analizler sonucunda iş stresinin toksik davranışlar ile pozitif yönlü anlamlı ilişki içinde olduğu ve iş stresinin toksik davranışlardaki değişimlerin \%o61,0'ını açıkladığı bulgulanmıştır.

Anahtar Kelimeler: Aşçı, iş stresi, toksik davranış.

\begin{abstract}
Stress, like in many sectors, has become one daily routine of people working in the tourism sector. Employees and managers have been working in changing and uncertain environments. Because most of the factors causing stress are in a nature that managers cannot control, employees and managers have difficulty in adapting to this environment. Especially chefs working in the kitchen of the hotels work under intense stress, hot and stifling atmosphere of the kitchen irritates the chefs and kitchen staff, and so they sometimes quarrel with other employees. Such conditions cause an increase in toxic behaviour of the chefs. The aim of this research is to investigate the relationship between job stress of the hotel chefs and their toxic behaviour. In this context, data has been collected by implementing a survey to 449 chefs working in five-star hotels in Turkey. The analysis showed that job stress has positive relationship with toxic behaviour and job stress explains $\% 061,0$ of changes in toxic behaviour.
\end{abstract}

Keywords: Chef, job stress, toxic behavior.

*Bu makale, "Otel İşletmelerinde Çalışan Aşçıların İş Stresi ile İş Tatmini, Örgütsel Bağlılık ve Toksik Davranışları Arasındaki İlişki” adlı doktora tez çalışmasından oluşturulmuştur. 


\section{Giriş}

Günümüzde müşterilerinin gereksinimlerine ve bakış açılarına önem vermeyen işletmelerin, rekabetin giderek yoğunlaştığı bir ortamda ayakta kalabilmeleri ve faaliyetlerini devam ettirebilmeleri çok da kolay olmamaktadır (Tekin ve Çiçek, 2005:66). Bunun için öncelikli olarak işletmelerin, çalışanlarını daha kaliteli hizmet sunabilecek şekilde eğitmesi, işe yönelik tutum ve davranışlarını doğru bir biçimde yönlendirebilmesi gerekmektedir (Saldamlı, 2000:292). Özellikle turizm sektöründe çalışan personelin iş stres seviyesinin azaltılması ve toksik davranışlarının kontrol altına alınması oldukça önemlidir. Zira stresi ve toksik davranışları makul düzeyde olan çalışanların müşteri memnuniyetine, hizmet kalitesine ve işletmenin başarısına daha fazla katkıda bulunacağı düşünülmektedir (Toker, 2007:93).

Otel işletmelerinde çalışan aşçılar çoğu zaman çalışma koşulları bakımından yoğun stres altında görevlerini ifa etmek durumunda kalmaktadırlar. Mutfağın operasyonel yoğunluğu ve kalabalıklığı (Borş, 2010:163), sıcak ve boğucu havası bu bölümde çalışan personeli asabileştirmekte ve bunun sonucu olarak da diğer işgörenler ile gereksiz tartışmalar ve kavgalar yaşanabilmektedir (Şener, 2001:304). Çoğu zaman yeterli sayıda personelin olmaması (Bloisi ve Hoel, 2008:653), ağırlama faaliyetlerinin haftanın yedi günü sürmesi, insanlarla sürekli iletişim içinde olunması ve aç insanların çalışan personel üzerinde oluşturduğu baskı gibi etkenler mutfak personelinde ve aşçılarda stresli davranışların gözlemlenmesine neden olabilmektedir (Üngüren, Doğan, Özmen ve Tekin, 2010:2926). Çalışma ortamlarının ısı ve nem düzeyi açısından olumsuz koşullara sahip olması ve sürekli ayakta çalışma aşçılarda stres ve yorgunluk kaynağı olarak kendini gösterebilmektedir (Sarışık, 2008:155).

İşletme içerisinde görülebilen, iğneleyici, alaycı sözler (Webber, 2011:6), saldırgan, kaba davranışlar (Holloway ve Kusy, 2010:26), tehdit ve gözdağı vererek yönetme, çalışanları rencide edici yaklaşımlar (Kong, 2011:156), aşırı kıskançlık, üstünlük ve sindirme vurgusu, aşırı denetim, sınırlı ast-üst ilişkileri gibi çalışma hayatında görülen toksik davranışlar (Pelletier, 2010:374), mutfakta çalışan aşçıların olumsuz duygular beslemesine, işe ve işletmeye karşı tepkisel yaklaşımına neden olabilmekte (Töremen ve Çankaya, 2008:37), böyle bir çalışma ortamında aşçılar yüksek düzeyde stres ve baskı hissedebilmekte (Singh, 2008:38), verimliliklerinde uzun vadede düşüşler gözlemlenebilmekte (Appelbaum ve Shapiro, 2006:15) kendilerini güçsüz hissedebilmekte, sürekli kaygı düzeyleri yüksek bir biçimde faaliyetlerini sürdürmeye çalışmaktadırlar (Kimlinger ve diğ., 2011:3).

Aşçıların otel işletmeleri için sahip olduğu önem derecesi göz önüne alınarak, araştırmanın amacı; iş stresi ile toksik davranışlar arasındaki ilişkiyi incelemektir. İş stresinin toksik davranışları etkileyip etkilemediğinin öğrenilmesi ile araştırmacılara ve uygulayıcılara önemli bilgilerin sağlanması mümkün olacaktır. Yapılacak olan bu çalışmanın diğer çalışmalardan en belirgin farkı; iş stresi ile toksik davranış değişkeni arasındaki ilişkiyi bir hizmet sektörü olarak kabul gören otel işletmelerinde hizmet veren "aşçılara" yönelik olarak kapsamlı bir araştırma niteliğinde ortaya koymaya çalışmasıdır. Literatürde aşçılara yönelik olarak yapılmış bu tarz bir çalışmaya rastlanmamıştır. Bu nedenle yapılan araştırmanın bir ilk olması ve özellikle iş deviniminin (devir hızının) oldukça yüksek olduğu bu sektörde aşçılık mesleğini icra eden kişilerin "stres kaynaklarını, stresin ortaya çıkarabileceği toksik davranışları" tespit etmek açısından yararlı sonuçlar ortaya koyabileceği düşünülmektedir. Bu nedenle çalışmada;

1. İş stresi ile toksik davranışlar arasında anlamlı bir ilişki var mıdır? 
2. İş stresinin toksik davranışlara anlamlı bir etkisi var mıdır? Sorularına cevap aranacaktır.

\section{Literatür Taraması}

\subsection{Stres Kavramı}

Stres kavramı günlük yaşamın ayrılmaz bir parçası haline gelmiş ve günümüzde her yaştan insanda bu ruh hali görülebilir olmuştur (Türk, Eroğlu ve Türk, 2008:3). Bir başka ifadeyle, stres bireyin yaşamının kaçınılmaz bir parçasıdır (Cho ve diğ., 2008:48). Sıkıca sarmak, sıkmak, sıkıştırmak, bağlamak, boğmak anlamlarını taşıyan stres (Tokmak ve diğ., 2011:50) Latince kökenli bir kelime olup (Ismail, Yao ve Yunus, 2009:4) zorlanma, gerilme ve baskı anlamlarına gelen "estrica", eski Fransızca'da ise "estrece" sözcüklerinden gelmektedir (Serinkan, Kaymakçı, Alişan ve Avcık, 2012:23). Dr. Hans Selye stres kavramını açıklayan ilk Kanadalı fizyoloji bilginidir. Selye, stresi, iç ve dış ortamdan kaynaklanan etkenlerin kişinin organizmasında yarattığı değişiklik olarak ifade etmiştir (Özdevecioğlu ve diğ., 2003:131).

Stres, kişilerin duygu ya da düşünce durumunu, çevresi ile mücadele edebilme gücünü tehdit ederek, bireylerin fizyolojik ve psikolojik dengesini bozan bir durum olarak ortaya çıkabilir (Akova ve Işık, 2008:18). Stres, kişilerin davranışlarını ve başkalarıyla olan ilişkilerini etkileyebilir. Ortaya çıkabilmesi için bireyin yaşadığı çevrede meydana gelen değişimlerin de kişiyi etkilemesi gerekmektedir (Özer, 2012:46). Dolayısıyla bireyin dışarıdan gelen tehditlere ve olaylara karşı göstermiş olduğu fiziksel ve duygusal tepki şeklinde ifade edilebilir (Erkutlu ve diğ., 2011:199). Stres kavramı kişileri fiziksel veya psikolojik açıdan rahatsız eden bir güç olarak da nitelendirilebilir (Gignac ve Appelbaum, 1997:22).

Stres, çift yönlü bir olgudur. Bu bakımdan her ne kadar olumsuz bir kavram gibi düşünülse de, olumlu bir değere de sahiptir. Olumlu ve doğru yönde kullanılan stres sorunların ortaya çıkmadan yok edilmesini sağlar (Özkaya ve diğ., 2008:164). Belirli bir düzeyde stres yüksek düzeyde iş tatminine, çalışanların işe yönelik istek ve beklentilerinin karşılanmasına ve yüksek düzeyde örgütsel bağlılığa yol açar (Moncrief ve diğ., 1997:795).

Aşırı stres ise bireylerin sağlığını ve ilişkilerini olumsuz yönde etkileyebilir. Aşırı stres yaşayan ve bu tür ortamlarda çalışan kişiler farklı tepkiler sergileyebilirler. Bu tepkiler içine kapanıklılıktan, sigara, içki vb. kötü alışkanlıklara yakalanmaya kadar değişik şekillerde ortaya çıkabilmektedir. Bu nedenle stresin kabul edilebilir bir düzeyde tutulması gerekmektedir. Çünkü stres kabul edilebilir ve zarar vermeyecek bir seviyede tutulabilirse hem çalışanlar hem de işletmeler açısından olumlu yönde kazanımlar sağlayabilir (Unur, 2011:233).

Günümüzde bireyler zamanlarının büyük bir bölümünü çalışma ortamlarında geçirmektedirler. Bu durum ise işin akışından veya karşılıklı ilişkilerden doğabilecek iş stresini ortaya çıkarabilmektedir (Erdoğan ve diğ., 2009:449). İş stresi çoğunlukla kişi ve iş çevresi arasında bir tutarsızlık olduğu zaman hissedilmekle birlikte (Allison, 1997:40) çalışma ortamındaki örgütsel, bireysel veya farklı nedenlerde iş stresini tetikleyebilmektedir (Adıgüzel, 2012:164). İş tanımlarının net olmayışı, çok fazla sorumluluk buna karşılık az yetkinin verilmesi, cinsiyete, dine, yaşa ilişkin önyargılar (Rosch ve Kenneth, 1987:147), kötü iş ilişkileri, adaletsiz maaş ödemeleri, şiddet, aşağılayıcı tavırlar, olumsuz çalışma koşulları, ağır iş yükü ve benzeri nedenler işyerinde stres oluşumuna neden olan etmenlerden sadece birkaçıdır (Ziauddin ve diğ., 2010:617). 
İ̧ stresi, işletmedeki tüm çalışanların performansını etkileyen bir unsurdur. Çalışma ortamında işgören devamsızlığı, performans düşüklüğü, motivasyon eksikliği, deneyimli personelin işten ayrılması gibi birçok olumsuz sonuç doğurabilmektedir (Campbell, 1995:22). Ayrıca işe yönelik beklentiler ve istekler çalışanın kapasitesini aştığında da kendisini gösterebilmekte, birey de bu durumu zararlı fiziksel ve duygusal tepkilerle dışa vurabilmektedir (Sarışık, 2008:152).

İş stresinin hissedildiği ortamlarda çalışanların iş tatmin düzeyleri, işletmeye olan bağlılıkları ve performansları üzerinde düşüşler yaşanabilmekte (Karimi ve Alipour, 2011:232) bireylerde, sinirlilik halleri, konsantrasyon bozuklukları, mantıklı bir şekilde karar verememe, yorgunluk ve uykusuzluk gibi sorunlar ortaya çıkabilmektedir (Malik, 2011:3064). Unutulmamalıdır ki stres doğal bir olaydır ve tüm işletmeler için kaçınılmaz bir sonuçtur (Gül, Oktay ve Gökçe, 2008:2). İş bir stres kaynağıdır ve çalışanların yeteneklerini sınırlayıcı etki yapar (Ergül, 2012:6). Ayrıca iş dışındaki faktörlerden kaynaklanan stres etmenleri belirli bir süre sonra iş ortamında da etkili olmaya başlar (Güney, 2007:596). Dolayısıyla, hem işletmelerin hem de çalışan bireylerin verimliliğini arttırabilmek için çalışma ortamındaki stres yoğunluğunun belirli bir düzeyde tutulması gerekmektedir (Yıldırım ve diğ., 2004:8). Çünkü stresli iş yaşamı, çalışanların gergin olmalarına, başkalarıyla anlaşamamalarına ve benzeri sorunlara yol açabilmektedir. Bu durum ise işgörme maliyetini yükseltebilmekte, çalışanların ve iş yaşamının niteliğini düşürebilmektedir (Soysal, 2009:19).

\subsection{Toksik Davranış Kavramı}

İşletme içerisinde ve çalışma hayatında sıklıkla görülebilen, iğneleyici, alaycı sözler (Webber, 2011:6), saldırgan, kaba davranışlar (Holloway ve Kusy, 2010:26), tehdit ve gözdağı vererek yönetme, çalışanları rencide edici yaklaşımlar (Kong, 2011:156), aşırı kıskançlık, üstünlük ve sindirme vurgusu, aşırı denetim, sınırlı ast-üst ilişkileri gibi davranışlar toksik davranışlar olarak kabul edilmektedir (Pelletier, 2010:374). Bu davranışlar bireylerin olumsuz duygular beslemesine, işe ve işletmeye karşı tepkisel yaklaşımına neden olabilmektedir (Töremen ve Çankaya, 2008:37). Toksik davranışları barındıran çalışma ortamlarında düşük üretim, çalışanların bazı değer ve tutumlarında kayıplar, moralde azalma gibi durumlar öne çıkabilmekte, bu davranışlar ise işletmeye ve çalışanlara ciddi zararlar verebilmektedir (Mines, Meyer and Mines, 2004:92).

Tablo 1:Çalışma Hayatında Toksik Davranış Göstergeleri

\begin{tabular}{|l|l|}
\hline Başkalarını aşağılama, alaycı sözler söyleme & Başkalarının düşüncelerine güvenmeme \\
\hline Yetkisini başkalarını cezalandırmak için kullanma & Pasif ve agresif davranışlar gösterme \\
\hline Yersiz ve düşünmeden eleştirme & Kendi alanını koruma \\
\hline Başkalarının hatalarını ortaya çıkarma & Çalışma arkadaşlarının davranışlarını gözetleme \\
\hline
\end{tabular}

Kaynak: Holloway, E. L. and Kusy, M. E. (2010). Disruptive and Toxic Behaviors in Healthcare: Zero Tolerance, The Bottom Line and What To Do About It. Medical Practice Management, 335-340.

Toksik davranışlara sahip olan çalışanlar genel olarak olumsuz bir tutum içerisinde olup sık sık öfkelenir ve çalışmak istemezler (Voorhees, 2011:3). Diğer çalışan personelin iş performansını ve moralini bozarlar (Frederick, 2009:62). Bir işletmedeki toksik yönetim tarzı, çalışanlar arasında umutsuzluk, kızgınlık, düşük moral, kötü iletişim ve depresyon gibi olumsuz etkilerin yayılmasında etkili olmaktadır (Appelbaum and Girard, 2007:21).

Toksik işletmelerde kişilik çatışmaları, kötü iş performansı (Snyder, 2010:18) ikiyüzlülük, kısıtlayıcılık, öfke krizleri (Gilbertve diğ., 2012:30) gibi tutumlar çalışma 
ortamının atmosferine nüfus eder (Chapman, 2009). Bu tarz işletmelerde toksik davranışlar kontrol altına alınamazsa üst düzey pozisyonda yer alan kişiler çalışanların işlerini daha karmaşık hale getirebilir, enerjilerini bitirebilir, akıl ve ruh sağlıkları üzerinde olumsuz etkiler bırakabilir ve kariyerlerini yok edebilirler (Lubit, 2004:1). Ayrıca çalışanlarda uyku bozuklukları, depresyon, bellek bozuklukları gibi psikolojik, hipertansiyon ve kas gerilimi gibi fizyolojik rahatsızlıklar gözlemlenebilir (Kimlinger ve diğ., 2011:4).

Toksik işletmeler genellikle amaçlarına ulaşmada yetersiz, zayıf iç iletişime sahip, kişilerarası ilişkilerde bencil ve çıkarcı davranışların ön plana çıktığı (Appelbaum ve Girard, 2007:18) çalışanların dedikodu yaptığı, birbirlerini küçümsediği, eleştirdiği, bireysel anlaşmazlıkların çok yoğun yaşandığı işletmelerdir (Bauer, 2008:15). Çalışanlar bu tarz işletmelerde genellikle birbirleri ile yüz yüze iletişim kurmaktan kaçınmakta sadece işine odaklanmakta yada tam tersi bir şekilde işten çok birbirleri ile ilgili söylentilerle oyalanarak işlerine gereken önemi vermemektedirler (Appelbaum, laconi ve Matousek, 2007:591).

\section{3. İş Stresi ve Toksik Davranışlar}

Literatürde doğrudan iş stresi ve bileşenlerinin toksik davranışlar ve bileşenleriyle arasındaki neden sonuç ilişkisini araştıran bir çalışmaya rastlanmamıştır. Ancak, liderlikle ilgili yapılan bazı çalışmalarda toksik davranış kavramı kullanılmıştır. Örneğin; Schaubroeck, Walumbwa, Ganster ve Kepes (2007) toksik lider davranışının emrinde çalışanlarda strese ve stresin de mide şikayetlerine, huzursuzluğa ve endişeye yol açtığını belirtmekte, bu durumun da çalışanların iş tatminini ve örgütsel bağlılıklarını azaltıp başka işler aramalarına yol açtığını söylemektedir. Tepper (2007) ise otoriter bir liderin kişilik özelliklerine, toksik davranışları eklenince, stresin de ötesinde çalışanlarda yıldırma algısı oluştuğunu belirtmektedir. Bir başka çalışmada ise Appelbaum ve Roy-Girard (2007: 17-28) toksik yöneticilerin, işletme çalışanları üzerinde asabiyet, anksiyete, odaklanma problemi ve hafıza yetilerinin azalması gibi bazı psikolojik etkileri olduğundan söz etmişlerdir. Scholten (2016) toksik bir işyerinin en önemli on göstergesinden birincisinin kronik yüksek stres olduğunu belirtmekte ve bu durumunda düşük performans, sağlık sorunları ve kalifiye personel kaybına yol açtığını söylemektedir. Bu bilgilerden hareketle çalışmanın amacı; otel işletmelerinde çalışan aşçıların iş stresi ile toksik davranışları arasındaki ilişkiyi incelemektir. Maitlis ve Özçelik (2004: 375-393) toksik karar verme sürecini, çalışanların birbirleriyle etkileşimli hareketleri ve olumsuz duyguları ile oluşan bir karar verme süreci olarak tanımlamışlardır. Dolayısıyla iş stresi ve bileşenlerinin, toksik davranışlar ve bileşenleri ile ilişkili olması olasıdır. İş stresi ve bileşenleri ile toksik davranışlar ve bileşenleri arasındaki korelâsyonun test edilmesi için aşağıdaki araştırma sorularına yanıt aranmaktadır;

1. İş stresi ile toksik davranışlar arasında anlamlı bir ilişki var mıdır?

2. İş stresinin alt boyutları ile toksik davranışlar arasında anlamlı bir ilişki var midır?

3. İş stresi ile toksik davranışların alt bileşenleri arasında anlamlı bir ilişki var mıdır?

4. İş stresinin toksik davranışlara anlamlı bir etkisi var mıdır?

5. İs stresinin alt bileşenlerinin toksik davranışlara anlamlı bir etkisi var mıdır?

6. İş stresinin toksik davranışların alt bileşenlerine anlamlı bir etkisi var mıdır?

\section{Araştırmanın Yöntemi}

\subsection{Araştırmanın Evreni ve Örneklemi}


Araştırmanın evrenini, Türkiye genelinde faaliyet gösteren beş yıldızlı otel işletmelerinde çalışan aşçılar ve aşçı yamakları oluşturmaktadır. Çalışma mutfakta çalışan bulaşıkçı, meydancı ve stajyerleri kapsamamaktadır. Aşçılar turizm sektöründeki tüm çalışanların maruz kaldıkları uzun çalışma saatleri (Şener, 2013:26), düşük ücret, aşırı iş yükü, işlerin çok kısa sürede bitirilmesi baskısı (Birdir ve Kılıçhan, 2013:984) gibi faktörlere ek olarak kapalı alan, yüksek sıcaklık, yüksek nem oranı gibi fiziki çalışma koşullarının olumsuzluklarıyla da (Hız, Karataş ve Uluksar, 2015:) baş etmeye çalışmaktadırlar. Dolayısıyla çalışmanın aşçılarla yapılmasının nedeni, yukarıda belirtilen olumsuzlukların yarattığı iş stresinin aşçılarda yüksek düzeyde olma olasılığı ve Türkiye'de aşçılara yönelik yapılmış böyle bir çalışmanın bulunmamasıdır. Beş yıldızlı otellerde yapılmasının nedeni ise, daha düşük yıldızlı otellere kıyasla daha iyi bilgiler elde edilebileceği varsayımı ve tüm otellere ulaşmanın zaman ve para açısından çok maliyetli olma olasılığıdır. Türkiye'de faaliyet gösteren beş yıldızıı otel işletmesi sayısı ikincil veri kaynaklarından tarama yapılarak tespit edilmiştir. Kültür ve Turizm Bakanlığı istatistikleri ve diğer ikincil verilerden elde edilen bilgiler doğrultusunda 2013 yılı itibariyle 550 adet beş yıldızlı konaklama işletmesinin fiilen faaliyette olduğu belirlenmiştir. Araştırma evreninin tamamına ulaşmanın zaman, maliyet, mesafe ve kontrol güçlüklerinden (Karasar, 2008:111) dolayı mümkün olmaması dikkate alınarak örnekleme yoluna gidilmiştir (Karasar, 2008:114). Örneklem alınabilmesi için evren büyüklüğünün belirlenmesi gerekmiştir. Bu bağlamda evren büyüklüğünü hesaplayabilmek için farklı bölgelerden ulaşılabilen 20 otel işletmesinin müdürleriyle görüşülmüştür. Her bir otelden mutfakta çalışan aşçı sayıları alınmıştır. Alınan aşçı sayılarının aritmetik ortalaması 23 olarak tespit edilmiştir. Toplam beş yıldızlı otel sayısı ile bu otellerde çalışan ortalama aşçı sayısı çarpılarak $(550 \times 23=$ 12.650) toplam aşçı sayısına ulaşılmıştır. Evren büyüklüğünün 12.650 olduğu bir çalışmada örnek büyüklüğünün 384 olması yeterli olarak görülmektedir (Altunışık ve diğ., 2005:127). Türkiye'nin yedi coğrafi bölgesinde yer alan otel sayıları baz alınarak her bölgeyi oransal olarak kapsayacak şekilde kota örneklemesi yapılmıştır. Bölge sınırları içerisinde kalmak şartıyla anketin uygulanmasına izin veren beş yıldızı otel işletmelerinde çalışan aşçılara anket uygulanmış, toplamda 422 anketten 22 tanesi eksik doldurulduğundan örnekleme dâhil edilmemiş, 400 anket geçerli sayılmış ve analiz edilmiştir. Daha sonradan pilot araştırma (75 anket) için toplanan veriler de, temel araştırma için toplanan verilere eklenmiştir. Yapılan çok değişkenli sapan analizi ve çıkarılan gözlemler sonucunda analizlere 449 anket ile devam edilmiştir.

\subsection{Veri Toplama Araçları}

Araştırmada veri toplama aracı olarak anket tekniğinden faydalanılmıştır. Soru formu oluşturulurken Tiritoğlu (2006)'nun yüksek lisans tezinde kullandığı ve Öztürk (2000) ve Kırel (1994)'in çalışmalarından yararlanarak oluşturduğunu söylediği 35 maddeden oluşan stres faktörleri ölçeğinin 2 maddesi mutfakla ilişkili olmadığı gerekçesiyle çıkarılmış ve 33 madde alınmıştır. Ayrıca Avcı (2007)'nın yüksek lisans tezinde kullandığı ve İnayet (2002), Mavili Aktaş (2001), Ataklı (1999) ve Ertekin (1990)'nın çalışmalarından derleme yaparak oluşturduğunu söylediği ve 18 maddeden oluşan stres faktörleri ölçeğinden Tiritoğlu (2006)'nun ölçeğinde yer almayan ve mutfakla ilişkili olduğu düşünülen 7 madde alınmıştır. Son olarak literatürden mutfakla ilişkili olduğu tespit edilen ve yararlanılan iki ölçekte de bulunmayan 4 madde eklenerek toplam 44 soruluk bir iş stresi soru formu oluşturulmuştur. Tüm sorular araştırmanın amacına uygun şekilde düzenlenmiş ve ölçeğe son hali verilmiştir. Toksik Davranışlar ölçeği için ise Kusy ve Holloway (2009)'in kullandığı ölçek Türkçeye uyarlandıktan sonra kullanılmıştır. Maddelerin Türkçeye çevrilmesi 3 öğretim üyesi tarafından ayrı ayrı yapılmıştır. 
Daha sonra araştırmacılar bir araya gelerek çeviriler karşılaştırılmış, farklılıklar üzerinde tartışılmış ve maddeler üç araştırmacının da hemfikir olduğu şekilde yazılmıştır. Çeviri yine iki dili ve kültürü iyi bilen, 2 öğretim üyesi tarafından da kontrol edilmiş ve tavsiyeleri alınarak küçük uyarlamalar yapılarak son şekli verilmiştir. Anketin uygulanacağı örneklemden 75 kişiyle ön test yapılarak ankete son şekli verilmiştir.

\subsection{Veri Analizi}

Araştırmadan elde edilen veriler istatistiksel paket programı yardımı ile bilgisayar ortamında analiz edilmiştir. Araştırma sorularına yanıt bulabilmek için korelasyon ve regresyon analizlerinden yararlanılmıştır.

\section{Araştırmanın Bulguları}

Araştırmaya katılanlarla ilgili demografik bilgilere sahip olmak amacıyla öncelikle frekans analizi yapılmıştır. Tablo 2'de araştırmaya katılan 449 aşçının cinsiyet, yaş, eğitim, medeni durum ve gelir durumları ile ilgili demografik bulgulara yer verilmektedir.

Tablo 2: Örneklem Grubuna İlişkin Demografik Bulgular

\begin{tabular}{|c|c|c|c|c|c|}
\hline & Frekans & Yüzde \% & & Frekans & Yüzde \% \\
\hline \multicolumn{3}{|l|}{ Cinsiyet } & \multicolumn{3}{|l|}{ Eğitim Durumu } \\
\hline Kadın & 54 & 12,0 & İlköğretim & 90 & 20,0 \\
\hline Erkek & 395 & 88,0 & Ortaöğretim & 94 & 20,9 \\
\hline Toplam & 449 & 100,0 & Lise ve Dengi & 179 & 39,9 \\
\hline \multicolumn{3}{|l|}{ Medeni Durum } & Önlisans & 45 & 10,0 \\
\hline Bekâr & 181 & 40,3 & Lisans & 35 & 7,8 \\
\hline Evli & 268 & 59,7 & Yüksek Lisans & 6 & 1,3 \\
\hline Toplam & 449 & 100,0 & Toplam & 449 & 100,0 \\
\hline \multicolumn{3}{|l|}{ Aylık Gelir } & \multicolumn{3}{|l|}{ Yaş Grubu } \\
\hline $800-1.500$ & 78 & 17,4 & 25 yaş ve altı & 98 & 21,8 \\
\hline $1.501-2.500$ & 189 & 42,1 & $26-35$ yaş arası & 187 & 41,6 \\
\hline $2.501-3.500$ & 103 & 22,9 & $36-45$ yaş arası & 128 & 28,5 \\
\hline $3.501-5.000$ & 27 & 6,0 & $46-55$ yaş arası & 34 & 7,6 \\
\hline $5.001-7.000$ & 35 & 7,8 & 56 yaş ve üstü & 2 & 4 \\
\hline $7.001-9.000$ & 9 & 2,0 & Toplam & 449 & 100,0 \\
\hline $9.001-12.000$ & 6 & 1,3 & & & \\
\hline $12.001-15.000$ & 1 & ,2 & & & \\
\hline 20.000 ve üstü & 1 & , & & & \\
\hline Toplam & 449 & 100,0 & & & \\
\hline
\end{tabular}

Tablo 2'deki veriler aşçıların çoğunluğunun (\%88) erkek ve evli $(\% 59,7)$ olduğunu göstermektedir. Ayrıca araştırmaya katılan aşçıların yalnızca \%8'inin 45 yaşından büyük olduğu, yaklaşık \%60'ının lise ve üstü ancak \%40'ının ilkokul ve ortaokul eğitim düzeyinde olduğu görülmektedir. Bu bilgilerden hareketle katılımcıların genellikle 26-35 ve 36-45 yaş arası yani "genç" ve "orta yaş" grubundan oldukları ve eğitim düzeylerin düşük olduğu söylenebilir. Katılımcıların yalnızca \%17,4'ünün 800-1500 TL arası aylık gelirleri olduğu görülmektedir.

Tablo 3'de araştırmaya katılan 449 aşçının mutfaktaki görevleri, kadro durumları, işletmede çalışma süreleri, çalıştıkları otel işletmesinin türü ve çalıştıkları konaklama işletmesinin statüsü ile ilgili işyeri özelliklerine ilişkin bulgulara yer verilmektedir. 
Tablo 3: Örneklem Grubunun İşyeri Özelliklerine İlişkin Bulgular

\begin{tabular}{|c|c|c|c|c|c|}
\hline & Frekans & Yüzde \% & & Frekans & Yüzde \% \\
\hline \multicolumn{3}{|l|}{ Mutfaktaki Göreviniz } & \multicolumn{3}{|c|}{ Kadro Durumunuz } \\
\hline Aşçıbaşı & 45 & 10,0 & Kadrolu & 279 & 62,1 \\
\hline Aşçıbaşı Yardımcısı & 38 & 8,5 & Sözleşmeli & 153 & 34,1 \\
\hline Bölüm Şefi & 19 & 4,2 & Yarı Zamanlı & 12 & 2,7 \\
\hline Sos Bölüm Şefi & 6 & 1,3 & Diğer & 5 & 1,1 \\
\hline Garnitür Bölüm Şefi & 1 & ,2 & Toplam & 449 & 100,0 \\
\hline Çorba Bölüm Şefi & 7 & 1,6 & \multicolumn{3}{|c|}{ İşletmede Çalışma Süresi } \\
\hline Izgara Bölüm Şefi & 23 & 5,1 & 1 yıldan az & 114 & 25,4 \\
\hline Soğuk Bölüm Sefi & 31 & 6.9 & $1-3$ yll & 173 & 38,5 \\
\hline Sıcak Bölüm Şefi & 20 & 4,5 & $4-6 \mathrm{yll}$ & 91 & 20,3 \\
\hline Ordövr Bölüm Şefi & 2 & 4 & $7-9 \mathrm{yıl}$ & 32 & 7,1 \\
\hline Sebze Bölüm Şefi & 3 & 7 & $10-12$ yıl & 18 & 4,0 \\
\hline Balık Bölüm Şefi & 17 & 3,8 & $13-15 \mathrm{yll}$ & 12 & 2,7 \\
\hline Pastane Bölüm Şefi & 7 & 1,6 & $16-18 \mathrm{yll}$ & 3 & ,7 \\
\hline Gece Şefi & 3 & ,7 & 19-21 yıl & 4 & ,9 \\
\hline Banket Şefi & 6 & 1,3 & $22-24$ yıl & 1 & ,2 \\
\hline Kahvaltı Aşçısı & 18 & 4,0 & 25 yıl ve üzeri & 1 & , \\
\hline Diyet Aşçısı & 4 & ,9 & Toplam & 449 & 100,0 \\
\hline Aşçı Yardımcısı & 43 & 9,6 & \multicolumn{3}{|c|}{ Calıştığınız Otel İşletmesinin Türü } \\
\hline Mutfak Komisi & 30 & 6,7 & Şehir Oteli & 364 & 81,1 \\
\hline Personel Yemek Aş & 114 & 25,4 & Kıyı Oteli & 79 & 17,6 \\
\hline Ala Carte Aşçısı & 11 & 2,4 & Diğer & 6 & 1,3 \\
\hline Diğer & 1 & 2 & Toplam & 449 & 100,0 \\
\hline Toplam & 449 & 100,0 & \multicolumn{3}{|c|}{$\begin{array}{l}\text { Çalıştığınız Konaklama İşletmesinin } \\
\text { Statüsü }\end{array}$} \\
\hline & & & Bağımsız & 112 & 24,9 \\
\hline & & & Zincir & 299 & 66,6 \\
\hline & & & Grup & 38 & 8,5 \\
\hline & & & Toplam & 449 & 100,0 \\
\hline
\end{tabular}

Tablo 3'teki veriler katılımcıların yalnızca \%62,1'inin daimi kadroda çalıştığı ve yaklaşık \%60'ının bölüm şefi, aşçıbaşı yardımcısı ve aşçıbaşı olduğu görülmektedir. Araştırmaya katılan aşçıların \%63,9'unun 3 yıldan daha kısa süredir aynı işletmede çalışması sektördeki yüksek iş devir hızının aşçılık mesleği içinde geçerli olabileceğini düşündürmektedir. Katılımcıların çoğunluğunun $(\% 81,1)$ şehir otelinde ve zincir otellerde $(\% 66,6)$ çalıştığı görülmektedir.

\subsection{Güvenilirlik Analizleri}

Araştırmada kullanılan her iki ölçek ile elde edilen verilerin güvenilirlik analizleri yapılmıştır. Verilerin güvenilirlik analizi için Cronbach Alpha güvenilirlik değerleri; İş stresi ölçeği için 0,940 , Toksik davranış ölçeği için 0,736 olarak bulunmuştur. Bu sonuçlar ankette yer alan ölçeklerin her birinin güvenirlik koşullarını sağladığını göstermektedir (Nakip, 2006:146).

\subsection{Faktör Analizleri}

Araştırmada yer alan iki ölçeğin faktör analizleri aşağıda yer almaktadır. Tablo 4'de Kaiser Meyer Olkin ölçek geçerliliği ,930 olarak bulunmuştur. Kalaycı'ya (2009) göre bu değerin, ,70'den büyük olması nedeniyle bu veriler üzerinden faktör analizi yapılabileceği sonucuna varılmıştır. İkinci olarak Bartlett Küresellik testine bakılarak ( $x 2$ = 7605.240; s.d.: 465; $p<0.001$ ) elde edilen veriler anlamlı farklılık gösterdiği için faktör analizi yapmaya uygun olduğu tespit edilmiştir (Kalaycı, 2009:428). Analiz sonucunda, öz değeri 1'in üzerinde olan yedi faktör (bileşen) olduğu bulgulanmıştır. Bu faktörlerin toplam varyansa yaptıkları katkı oranı \% 65,837'dir. 
Tablo 4: İ̧ Stresi Ölçeğinin Faktör Analizi

\begin{tabular}{|c|c|c|c|c|c|c|c|}
\hline IŞ STRESi & & $\begin{array}{l}\frac{\grave{\Phi}}{\frac{\Phi}{0}} \\
\stackrel{\Phi}{ \pm}\end{array}$ & 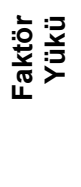 & 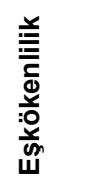 & 嗃 & 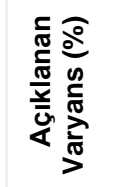 & $\frac{\pi}{4}$ \\
\hline \multirow{8}{*}{$\begin{array}{r}\text { Kişilerarası } \\
\text { ilişkilerden } \\
\text { Kaynaklanan } \\
\text { Stres } \\
\text { Faktörleri }\end{array}$} & is34 & $\begin{array}{l}\text { Mutfakta hak ettiğim ilgi, sevgi } \\
\text { ve takdiri görememek bende } \\
\text { stres oluşturur. }\end{array}$ & ,836 & 823 & \multirow{8}{*}{11,443} & \multirow{8}{*}{36,914} & \multirow{8}{*}{922} \\
\hline & is32 & $\begin{array}{l}\text { Mutfakta iş arkadaşlarımla } \\
\text { çatışmalar yaşamak bende } \\
\text { stres oluşturur. }\end{array}$ & ,806 & 808 & & & \\
\hline & is 33 & $\begin{array}{l}\text { Mutfakta iş arkadaşlarımın } \\
\text { düşmanca davranması bende } \\
\text { stres oluşturur. }\end{array}$ & ,741 & 724 & & & \\
\hline & is31 & $\begin{array}{l}\text { Mutfakta iş arkadaşlarımla } \\
\text { rekabet içinde olmak bende } \\
\text { stres oluşturur. }\end{array}$ & ,733 & 768 & & & \\
\hline & is35 & $\begin{array}{l}\text { Iş arkadaşlarımdan ve } \\
\text { şeflerimden destek alamamak } \\
\text { bende stres oluşturur. }\end{array}$ & ,727 & ,716 & & & \\
\hline & is36 & $\begin{array}{l}\text { Mutfakta dedikodunun yaygın } \\
\text { oluşu bende stres oluşturur. }\end{array}$ & ,705 & 694 & & & \\
\hline & is 37 & $\begin{array}{l}\text { Mutfakta yıldırmaya maruz } \\
\text { kalmak bende stres oluşturur. }\end{array}$ & ,616 & 623 & & & \\
\hline & is 30 & $\begin{array}{l}\text { Mutfakta bölüm şefleriyle } \\
\text { sorunlar yaşamak bende stres } \\
\text { oluşturur. }\end{array}$ & ,480 & ,515 & & & \\
\hline \multirow{6}{*}{$\begin{array}{r}\text { Örgütsel } \\
\text { Politikalardan } \\
\text { Kaynaklanan } \\
\text { Stres } \\
\text { Faktörleri }\end{array}$} & is5 & $\begin{array}{l}\text { Mutfakta birbiriyle çelişen iki işi } \\
\text { birden yapmak bende stres } \\
\text { oluşturur. }\end{array}$ & ,756 & 681, & \multirow{6}{*}{2,112} & \multirow{6}{*}{6,813} & \multirow{6}{*}{853} \\
\hline & is7 & $\begin{array}{l}\text { Mutfakta aşırı disiplinli bir } \\
\text { çalışma ortamının olması } \\
\text { bende stres oluşturur. }\end{array}$ & ,712 & ,618 & & & \\
\hline & is3 & $\begin{array}{l}\text { Mutfağın farklı bölümlerinde } \\
\text { çalışmak bende stres oluşturur. }\end{array}$ & ,685 & 637, & & & \\
\hline & is8 & $\begin{array}{l}\text { Mutfakta yeteneklerimi } \\
\text { kullanamadığım bir bölümde } \\
\text { çalışmak bende stres oluşturur. }\end{array}$ & ,614 & 647, & & & \\
\hline & is6 & $\begin{array}{l}\text { Performans değerlendirme ve } \\
\text { terfide adaletsizlik bende stres } \\
\text { oluşturur. }\end{array}$ & ,583 & 626 & & & \\
\hline & is11 & $\begin{array}{l}\text { Üst yönetimin kararlarına } \\
\text { katılamamak bende stres } \\
\text { oluşturur. }\end{array}$ & ,611 & 630 & & & \\
\hline \multirow{4}{*}{$\begin{array}{l}\text { Bireysel Stres } \\
\text { Faktörleri }\end{array}$} & is43 & $\begin{array}{l}\text { Isşten çok geç saatte çıkmak } \\
\text { bende stres oluşturur. }\end{array}$ & ,795 & ,712 & \multirow{3}{*}{1,755} & \multirow{3}{*}{5,661} & \multirow{3}{*}{784} \\
\hline & is 44 & $\begin{array}{l}\text { Mutfakta hiyerarşi bende stres } \\
\text { oluşturur. }\end{array}$ & ,739 &, 640 & & & \\
\hline & is 38 & $\begin{array}{l}\text { Özel yaşamıma yeteri kadar } \\
\text { zaman ayıramamak bende } \\
\text { stres oluşturur. }\end{array}$ & ,675 & ,585 & & & \\
\hline & is39 & $\begin{array}{l}\text { Yaptığım işin aldığım eğitime } \\
\text { uygun olmaması bende stres } \\
\text { oluşturur. }\end{array}$ & ,645 & ,636 & & & \\
\hline
\end{tabular}


Tablo 4'ün Devamı

\begin{tabular}{|c|c|c|c|c|c|c|c|}
\hline \multirow{3}{*}{$\begin{array}{r}\text { Örgütsel } \\
\text { Yapıdan } \\
\text { Kaynaklanan } \\
\text { Stres } \\
\text { Faktörleri }\end{array}$} & is1 & $\begin{array}{l}\text { Yetersiz maaş veya ücret } \\
\text { dengesizliği bende stres } \\
\text { oluşturur. }\end{array}$ & ,786 & ,695 & \multirow{3}{*}{1,527} & \multirow{3}{*}{4,924} & \multirow{3}{*}{772} \\
\hline & is2 & $\begin{array}{l}\text { Yetki ve sorumluluklarda } \\
\text { uyumsuzluk bende stres } \\
\text { oluşturur. }\end{array}$ & ,749 & ,727 & & & \\
\hline & Is9 & $\begin{array}{l}\text { Karar vermek için yeterli } \\
\text { yetkiye sahip olmamak bende } \\
\text { stres oluşturur }\end{array}$ & ,691 & ,586 & & & \\
\hline \multirow{3}{*}{$\begin{array}{r}\text { Çalışma } \\
\text { Ortamından } \\
\text { Kaynaklanan } \\
\text { Stres } \\
\text { Faktörleri }\end{array}$} & is18 & $\begin{array}{l}\text { Mutfakta gerekli araç gereç } \\
\text { eksikliği bende stres oluşturur. }\end{array}$ & ,665 & ,757 & \multirow{3}{*}{1,303} & \multirow{3}{*}{4,204} & \multirow{3}{*}{805} \\
\hline & is19 & $\begin{array}{l}\text { Mutfakta tehlikeli çalışma } \\
\text { ortamının varlığı bende stres } \\
\text { oluşturur. }\end{array}$ & ,588 & ,647 & & & \\
\hline & is16 & $\begin{array}{l}\text { Mutfakta aydınlatmanın } \\
\text { yetersiz olması bende stres } \\
\text { oluşturur. }\end{array}$ &, 547 & 705 & & & \\
\hline \multirow{3}{*}{$\begin{array}{r}\text { İşin } \\
\text { Yapısından } \\
\text { Kaynaklanan } \\
\text { Stres } \\
\text { Faktörleri }\end{array}$} & is 27 & $\begin{array}{l}\text { Müşteri memnuniyetsizliği ve } \\
\text { şikâyet edilme korkusu bende } \\
\text { stres oluşturur }\end{array}$ & ,752 &, 661 & \multirow{3}{*}{1,212} & \multirow{3}{*}{3,911} & \multirow{3}{*}{712} \\
\hline & is 23 & $\begin{array}{l}\text { Çalışma saatlerinin uzun } \\
\text { olması bende stres oluşturur. }\end{array}$ & ,703 & ,603 & & & \\
\hline & is20 & $\begin{array}{l}\text { Çalıştığım işyerine ulaşımdaki } \\
\text { zorluklar bende stres oluşturur. }\end{array}$ & ,608 &, 617 & & & \\
\hline \multirow{4}{*}{$\begin{array}{r}\text { Fiziki } \\
\text { Şartlardan } \\
\text { Kaynaklanan } \\
\text { Stres } \\
\text { Faktörleri }\end{array}$} & IS14 & $\begin{array}{l}\text { Mutfağın kalabalık olması } \\
\text { bende stres oluşturur. }\end{array}$ &, 647 &, 551 & \multirow{4}{*}{1,057} & \multirow{4}{*}{3,410} & \multirow{4}{*}{680} \\
\hline & is 15 & $\begin{array}{l}\text { Mutfağın çok gürültülü olması } \\
\text { bende stres oluşturur. }\end{array}$ & ,614 & ,655 & & & \\
\hline & is13 & $\begin{array}{l}\text { Mutfağın çok sıcak olması } \\
\text { bende stres oluşturur. }\end{array}$ &, 597 &, 540 & & & \\
\hline & is17 & $\begin{array}{l}\text { Mutfakta havalandırmanın } \\
\text { yetersiz olması bende stres } \\
\text { oluşturur. }\end{array}$ & ,493 & ,582 & & & \\
\hline
\end{tabular}

Toksik davranışlar ölçeğinin KMO değeri ,747 olarak bulunmuştur. İkinci olarak Bartlett Küresellik testine bakılarak ( $x 2=581,090$; s.d.: 15 ; $p<0.001)$ ulaşılan sonuçlar anlamlı farklıık gösterdiği için faktör analizi yapmaya uygun olduğu tespit edilmiştir (Kalaycı, 2009:428). Analiz sonucunda, öz değeri 1'in üzerinde olan iki faktör (bileşen) olduğu bulgulanmıştır. Bu faktörlerin toplam varyansa yaptıkları katkı oranı \% 61,748 'dir.

Tablo 5: Toksik Davranışlar Ölçeğinin Faktör Analizi

\begin{tabular}{|c|c|c|c|c|c|c|c|}
\hline $\begin{array}{c}\text { TOKSIKK } \\
\text { DAVRANIŞLAR }\end{array}$ & & 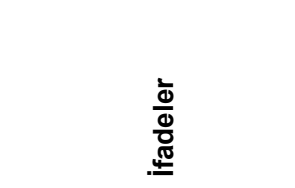 & 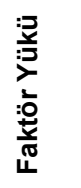 & 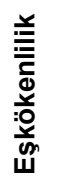 & 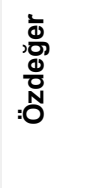 & 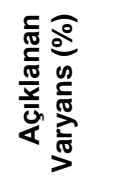 & $\frac{\pi}{4}$ \\
\hline \multirow{2}{*}{$\begin{array}{r}\text { Sabote Edici } \\
\text { Davranışlar }\end{array}$} & TD4 & $\begin{array}{l}\text { Mutfakta çalışanların } \\
\text { fikirlerine güvenilmez, } \\
\text { sürekli şüphe duyulur. }\end{array}$ & ,823 & ,681 & \multirow{2}{*}{2,639} & \multirow{2}{*}{43,981} & \multirow{2}{*}{, 749} \\
\hline & TD8 & $\begin{array}{l}\text { Mutfak çalışanları } \\
\text { agresif davranışlarla } \\
\text { karşılaşmaktadır. }\end{array}$ & ,756 & ,589 & & & \\
\hline
\end{tabular}


Tablo 5'in Devam

\begin{tabular}{|c|c|c|c|c|c|c|c|}
\hline & TD1 & $\begin{array}{l}\text { Mutfakta küçük } \\
\text { düşürücü davranışlara } \\
\text { maruz kalınmaktadır. }\end{array}$ & ,696 & 495 & & & \\
\hline & TD2 & $\begin{array}{l}\text { Mutfak çalışanları } \\
\text { iğneleyici sözlerle karşı } \\
\text { karşıya kalmaktadır. }\end{array}$ & ,636 & ,632 & & & \\
\hline \multirow{2}{*}{$\begin{array}{l}\text { Mahçup Edici } \\
\text { D Davranışlar }\end{array}$} & TD12 & $\begin{array}{l}\text { Mutfak çalışanlarının } \\
\text { hataları ortaya } \\
\text { çıkarıımaya çalışılır. }\end{array}$ & ,825 & ,681 & \multirow{2}{*}{1,066} & \multirow{2}{*}{17,766} & \multirow{2}{*}{ 478 } \\
\hline & TD3 & $\begin{array}{l}\text { Mutfakta çalışanlar } \\
\text { sürekli eleştirilere maruz } \\
\text { kalmaktadır. }\end{array}$ & 747 & ,627 & & & \\
\hline \multicolumn{8}{|c|}{$\begin{array}{l}\text { Varimax Rotasyonlu Temel Bileşenler Analizi - Açılanan toplam varyans: \% 61,748, KMO Örneklem Yeterliliği: ,747 - Bartlett } \\
\text { Küresellik Testi: : X²:581,090 s.d.: } 15 \text { p<0.001, Ölçeğin Tamamı için Alfa: ,736 Yanıt kategorileri: (1) Kesinlikle Katılmıyorum } \\
\text { (2) Katılmıyorum (3) Kararsızım (4) Katılıyorum (5) Kesinlikle Kałılıyorum }\end{array}$} \\
\hline
\end{tabular}

\subsection{Korelâsyon Analizi}

İş stresi ve bileşenleri olan örgütsel politikalardan kaynaklanan stres faktörleri, örgütsel yapıdan kaynaklanan stres faktörleri, iş ortamındaki fiziksel şartlardan kaynaklanan stres faktörleri, işin yapısı ile ilgili stres faktörleri, kişilerarası ilişkilerden kaynaklanan stres faktörleri, bireysel stres faktörleri ile toksik davranışlar ve bileşenleri olan sabote edici davranışlar, mahçup edici davranışlar arasındaki ilişkiler korelasyon analizi ile test edilmiştir. Analiz sonucunda elde edilen bulgular Tablo 6'da özetlenmektedir.

Tablo 6: İş Stresi ve Bileşenleri ile Toksik Davranış ve Bileşenleri Arasındaki Korelâsyona Yönelik Bulgular

\begin{tabular}{|c|c|c|c|c|}
\hline & & $\begin{array}{c}\text { Toksik } \\
\text { Davranış }\end{array}$ & $\begin{array}{l}\text { Sabote Edici } \\
\text { Davranışlar }\end{array}$ & $\begin{array}{c}\text { Mahçup Edici } \\
\text { Davranışlar }\end{array}$ \\
\hline \multirow{3}{*}{ İş Stresi } & $\begin{array}{l}\text { Pearson } \\
\text { Correlation }\end{array}$ &, $246^{\star *}$ &, $275^{\star *}$ & ,087 \\
\hline & Sig. (2-tailed) & ,000 &, 000 & ,065 \\
\hline & $\mathbf{N}$ & 449 & 449 & 449 \\
\hline \multirow{3}{*}{$\begin{array}{l}\text { Örgütsel } \\
\text { Politikalar }\end{array}$} & $\begin{array}{l}\text { Pearson } \\
\text { Correlation }\end{array}$ &, $241^{* *}$ & & \\
\hline & Sig. (2-tailed) &, 000 & & \\
\hline & $\mathbf{N}$ & 449 & & \\
\hline \multirow{3}{*}{$\begin{array}{l}\text { Örgütsel } \\
\text { Yapı }\end{array}$} & $\begin{array}{l}\text { Pearson } \\
\text { Correlation }\end{array}$ &, $184^{* *}$ & & \\
\hline & Sig. (2-tailed) & ,000 & & \\
\hline & $\mathbf{N}$ & 449 & & \\
\hline \multirow{3}{*}{$\begin{array}{l}\text { Fiziksel } \\
\text { Şartlar }\end{array}$} & $\begin{array}{l}\text { Pearson } \\
\text { Correlation }\end{array}$ &, $142^{* *}$ & & \\
\hline & Sig. (2-tailed) & ,003 & & \\
\hline & $\mathbf{N}$ & 449 & & \\
\hline \multirow{3}{*}{ İşin Yapısı } & $\begin{array}{l}\text { Pearson } \\
\text { Correlation }\end{array}$ &, $159^{* *}$ & & \\
\hline & Sig. (2-tailed) &, 000 & & \\
\hline & $\mathbf{N}$ & 449 & & \\
\hline \multirow{3}{*}{$\begin{array}{l}\text { Kişilerarası } \\
\text { İlişkiler }\end{array}$} & $\begin{array}{l}\text { Pearson } \\
\text { Correlation }\end{array}$ & $201^{* *}$ & & \\
\hline & Sig. (2-tailed) &, 000 & & \\
\hline & $\mathbf{N}$ & 449 & & \\
\hline \multirow{3}{*}{$\begin{array}{l}\text { Bireysel } \\
\text { Stres }\end{array}$} & $\begin{array}{l}\text { Pearson } \\
\text { Correlation }\end{array}$ &, $112^{*}$ & & \\
\hline & Sig. (2-tailed) & ,018 & & \\
\hline & $\mathbf{N}$ & 449 & & \\
\hline
\end{tabular}


Yapılan korelasyon analizi sonucunda şu bulgulara ulaşıımıştır. Aşçıların iş stres düzeyleri ile toksik davranış düzeyleri arasında pozitif yönlü ve anlamlı bir ilişki vardır $(r=0,246 ; p<0,01)$. Aşçıların iş stres düzeyleri arttıkça, mutfaktaki toksik davranış algısı da artmakta; iş stres düzeyleri azaldıkça, mutfaktaki toksik davranış algısı da azalmaktadır.

Aşçıların örgütsel politikalardan kaynaklanan stres düzeyleri ile toksik davranış düzeyleri arasında pozitif yönlü ve anlamlı bir ilişki vardır $(r=0,241 ; p<0,01)$. Aşçıların örgütsel politikalardan kaynaklanan stres düzeyleri arttıkça, mutfaktaki toksik davranış algısı da artmakta; örgütsel politikalardan kaynaklanan stres düzeyleri azaldıkça, mutfaktaki toksik davranış algısı da azalmaktadır. Aşçıların örgütsel yapıdan kaynaklanan stres düzeyleri ile toksik davranış düzeyleri arasında pozitif yönlü ve anlamlı bir ilişki vardır $(r=0,184 ; p<0,01)$. Aşçıların örgütsel yapıdan kaynaklanan stres düzeyleri arttıkça, mutfaktaki toksik davranış algısı da artmakta; örgütsel yapıdan kaynaklanan stres düzeyleri azaldıkça, mutfaktaki toksik davranış algısı da azalmaktadır.

Aşçıların iş ortamındaki fiziksel şartlardan kaynaklanan stres düzeyleri ile toksik davranış düzeyleri arasında pozitif yönlü ve anlamlı bir ilişki vardır $(r=0,142 ; p<0,01)$. Aşçıların iş ortamındaki fiziksel şartlardan kaynaklanan stres düzeyleri arttıkça, mutfaktaki toksik davranış algısı da artmakta; iş ortamındaki fiziksel şartlardan kaynaklanan stres düzeyleri azaldıkça, mutfaktaki toksik davranış algısı da azalmaktadır. Aşçıların işin yapısı ile ilgili stres düzeyleri ile toksik davranış düzeyleri arasında pozitif yönlü ve anlamlı bir ilişki vardır $(r=0,159 ; p<0,01)$. Aşçıların işin yapısı ile ilgili stres düzeyleri arttıkça, mutfaktaki toksik davranış algısı da artmakta; işin yapısı ile ilgili stres düzeyleri azaldıkça, mutfaktaki toksik davranış algısı da azalmaktadır.

Aşçıların kişilerarası ilişkilerden kaynaklanan stres düzeyleri ile toksik davranış düzeyleri arasında pozitif yönlü ve anlamlı bir ilişki vardır $(r=0,201 ; p<0,01)$. Aşçıların kişilerarası ilişkilerden kaynaklanan stres düzeyleri arttıkça, mutfaktaki toksik davranış algısı da artmakta; kişilerarası ilişkilerden kaynaklanan stres düzeyleri azaldıkça, mutfaktaki toksik davranış algısı da azalmaktadır.

Aşçıların bireysel stres düzeyleri ile toksik davranış düzeyleri arasında pozitif yönlü ve anlamlı bir ilişki vardır $(r=0,112 ; p<0,01)$. Aşçıların bireysel stres düzeyleri arttıkça, mutfaktaki toksik davranış algısı da artmakta; bireysel stres düzeyleri azaldıkça, mutfaktaki toksik davranış algısı da azalmaktadır. Aşçıların iş stres düzeyleri ile sabote edici davranış düzeyleri arasında pozitif yönlü ve anlamlı bir ilişki vardır ( $r=$ $0,275 ; p<0,01)$. Aşçıların iş stres düzeyleri arttıkça, mutfaktaki sabote edici davranış algısı da artmakta; iş stres düzeyleri azaldıkça, mutfaktaki sabote edici davranış algısı da azalmaktadır. Aşçıların iş stres düzeyleri ile mahçup edici davranış düzeyleri arasında yapılan korelasyon analizi sonucunda iki değişken arasında istatistiksel olarak anlamlı bir ilişki bulunamamıştır $(r=, 087 ; \mathrm{p}>, 001)$.

\subsection{Regresyon Analizi}

\subsection{1 İş Stresi ile Toksik Davranışlar Arasındaki Regresyonel illişkiye Yönelik Bulgular}

İş stresi bağımsız, toksik davranışlar bağımlı değişken olmak üzere değişkenler arasındaki doğrusal ilişkileri test etmek, toksik davranışlardaki değişimin ne kadarının iş stresi tarafından açıklanabildiğini araştırmak ve değişkenler arasındaki ilişkiyi matematiksel olarak ifade etmek amacıyla çoklu doğrusal regresyon analizi yapılmıştır. Analiz sonucunda elde edilen bulgular Tablo 7'de özetlenmektedir. 
Tablo 7: İş Stresinin Toksik Davranışlara Etkisi

\begin{tabular}{|l|c|c|c|c|c|c|c|}
\hline \multirow{2}{*}{ Model } & \multicolumn{2}{|c|}{$\begin{array}{c}\text { Standardize } \\
\text { Edilmemiş Katsayılar }\end{array}$} & $\begin{array}{c}\text { Standardize } \\
\text { Katsayılar }\end{array}$ & T & $\begin{array}{c}\text { Anlam } \\
\text { Düzeyi }\end{array}$ & Tolerans & V.I.F. \\
\cline { 2 - 7 } & B & Std. Hata & Beta & & & \\
\hline (Sabit) & 1,552 &, 152 & & 10,176 &, 000 & & \\
\hline İş Stresi &, 261 &, 049 &, 246 & 5,365 &, 000 & 1,000 & 1,000 \\
\hline \multicolumn{7}{|c|}{ Bağımlı Değişken: Toksik Davranışlar } \\
\hline \multicolumn{7}{|c|}{$R: 0,246 ; R^{2}: 0,061 ;$ Düzeltilmiş $R^{2}: 0,058 ;$ Model için F:28,785; $p=0,000 ;$ s.d.: 1; D-W: 0,895} \\
\hline
\end{tabular}

Yapılan basit doğrusal regresyon analizi sonuçları incelendiğinde modelin anlamlı $(F=28,785 ; p<0,05)$ olduğu görülmektedir. Varyans şişme değeri olarak adlandırılan VIF değeri 1,000 olarak bulgulanmıştır ve çoklu bağlantı sorunu olmadığı $(\mathrm{VIF}<10)$ söylenebilir. Oto korelasyona işaret eden D-W değeri 0,895 olarak bulgulanmıştır. $\mathrm{Bu}$ bulgu oto korelasyon olmadığının göstergesidir. Regresyon katsayılarının anlamlılığına işaret eden $t$ istatistiği $(t=5,365 ; p<0,05)$ anlamlıdır. İş stresi ile toksik davranışlar arasındaki ilişkinin, istatistiksel olarak anlamlı $(p<0,05)$ olduğu söylenebilir. Değişkenler arasında pozitif yönlü bir ilişki $(R=0,246)$ vardır. Bağımsız değişkenin bağımlı değişkeni açıklama oranı olan $R^{2}$ değeri 0,061 olarak hesaplanmıştır. Bu sonuç, toksik davranışlardaki değişimlerin \%o61,0'ının, iş stresi ile açıklandığını göstermektedir. İş stresindeki 1 birimlik artış, toksik davranışları 0,246 birim artırmaktadır. Elde edilen verilere ilişkin basit doğrusal regresyon modeli; $a=1,552$ ve $b=0,246$ olmak üzere $Y=a+b X$ ise $Y=1,552+0,246 X$ olarak kurulabilir.

\subsection{2. İş Stresi Bileşenleri ile Toksik Davranışlar Arasındaki Regresyonel İlişkiye Yönelik Bulgular}

Örgütsel politikalardan kaynaklanan stres faktörleri, örgütsel yapıdan kaynaklanan stres faktörleri, iş ortamındaki fiziksel şartlardan kaynaklanan stres faktörleri, işin yapısı ile ilgili stres faktörleri, kişilerarası ilişkilerden kaynaklanan stres faktörleri, bireysel stres faktörleri olarak sıralanan iş stresi bileşenleri bağımsız, toksik davranışlar bağımlı değişken olmak üzere değişkenler arasındaki doğrusal ilişkileri test etmek, toksik davranışlardaki değişimin ne kadarının iş stresi bileşenleri tarafından açıklanabildiğini araştırmak ve değişkenler arasındaki ilişkiyi matematiksel olarak ifade etmek amacıyla çoklu doğrusal regresyon analizi yapılmıştır. Analiz sonucunda elde edilen bulgular Tablo 8'de özetlenmektedir.

Tablo 8: İş Stresi Bileşenlerinin Toksik Davranışlara Etkisi

\begin{tabular}{|c|c|c|c|c|c|c|c|}
\hline \multirow[b]{2}{*}{ Model } & \multicolumn{2}{|c|}{$\begin{array}{c}\text { Standardize Edilmemiş } \\
\text { Katsayılar }\end{array}$} & \multirow{2}{*}{$\begin{array}{c}\begin{array}{c}\text { Standardize } \\
\text { Katsayılar }\end{array} \\
\text { Beta }\end{array}$} & \multirow[t]{2}{*}{$\mathbf{t}$} & \multirow{2}{*}{$\begin{array}{l}\text { Anlam } \\
\text { Düzeyi }\end{array}$} & \multirow[t]{2}{*}{ Tolerans } & \multirow[t]{2}{*}{ V.I.F. } \\
\hline & B & Std. Hata & & & & & \\
\hline (Sabit) & 1,604 & ,164 & & 9,805 & ,000 & & \\
\hline Örgütsel Politika &, 132 & ,052 & ,160 & 2,529 & 012 &, 527 & 1,897 \\
\hline Örgütsel Yapı &, 055 & ,042 & ,071 & 1,295 & ,196 & ,695 & 1,439 \\
\hline Fiziksel Şartlar &, 019 & ,054 & ,021 & ,358 & ,720 & ,615 & 1,626 \\
\hline İşin Yapısı &, 031 &, 042 &, 040 & ,722 & ,471 & ,679 & 1,473 \\
\hline Kişilerarası İlişkiler &, 036 & ,052 & ,046 & ,680 & ,497 & ,466 & 2,145 \\
\hline Bireysel stres &,- 019 & ,048 &,- 023 &,- 397 & ,691 & ,631 & 1,586 \\
\hline \multicolumn{8}{|c|}{ Bağımlı Değişken: Toksik Davranışlar } \\
\hline \multicolumn{8}{|c|}{$R: 0,260 ; R^{2}: 0,068$; Düzeltilmiş $R^{2}: 0,055$; Model için F:5,350; $p=0,000 ;$ s.d.: 6; D-W:,0,915 } \\
\hline
\end{tabular}


Yapılan çoklu doğrusal regresyon analizi sonuçları incelendiğinde modelin anlamlı $(F=5,350 ; \quad p<0,05)$ olduğu görülmektedir. Varyans şişme değeri olarak adlandırılan VIF değerleri; en düşük 1,439 ve en yüksek 2,145 olarak bulgulanmıştır ve çoklu bağlantı sorunu olmadığı $(\mathrm{VIF}<10)$ söylenebilir. Oto korelasyona işaret eden $\mathrm{D}-\mathrm{W}$ değeri, 0,915 olarak bulgulanmıştır. Bu bulgu oto korelasyon olmadığının göstergesidir. Regresyon katsayılarının anlamlılığına işaret eden $\mathrm{t}$ istatistikleri; yalnızca örgütsel politikalardan kaynaklanan stres faktörleri $(t=2,529 ; p<0,05)$ için anlamlıdır. Bir başka anlatımla iş stresi bileşenlerinden sadece örgütsel politikalardan kaynaklanan stres faktörleri ile toksik davranışlar arasındaki ilişkilerin, istatistiksel olarak anlamlı $(p<0,05)$ ve bu ilişkinin pozitif yönlü $(R=0,260)$ olduğu söylenebilir. Bağımsız değişkenin (örgütsel politikalardan kaynaklanan stres faktörleri) bağımlı değişkeni açıklama oranı olan $R^{2}$ değeri 0,068 olarak hesaplanmıştır. $\mathrm{Bu}$ sonuç, toksik davranışlardaki değişimlerin \%o68,0'ının, iş stresi bileşenlerinden örgütsel politikalardan kaynaklanan stres faktörleri ile açıklandığını göstermektedir. Örgütsel politikalardan kaynaklanan stres faktörlerindeki 1 birimlik artış, toksik davranışları 0,160 birim artırmaktadır. Elde edilen verilere ilişkin çoklu doğrusal regresyon modeli; $a=1,604$ ve $b=0,160$ olmak üzere $\left(Y=a+b X_{1}+c X_{2}+d X_{3}+\ldots\right)$ ise $Y=1,604+0,160 X_{1}$ olarak kurulabilir. Toksik davranışları açıklamada stresin diğer alt boyutlarının etkisi bulunmamaktadır.

\subsection{3. İş Stresi ile Sabote Edici Davranışlar Arasındaki Regresyonel İlişkiye Yönelik Bulgular}

İş stresi bağımsız, sabote edici davranışlar bağımlı değişken olmak üzere değişkenler arasındaki doğrusal ilişkileri test etmek, sabote edici davranışlardaki değişimin ne kadarının iş stresi tarafından açıklanabildiğini araştırmak ve değişkenler arasındaki ilişkiyi matematiksel olarak ifade etmek amacıyla çoklu doğrusal regresyon analizi yapılmıştır. Analiz sonucunda elde edilen bulgular Tablo 9'da özetlenmektedir.

Tablo 9: İş Stresinin Sabote Edici Davranışlara Etkisi

\begin{tabular}{|l|c|c|c|c|c|c|c|}
\hline \multirow{2}{*}{ Model } & $\begin{array}{c}\text { Standardize Edilmemiş } \\
\text { Katsayılar }\end{array}$ & $\begin{array}{c}\text { Standardize } \\
\text { Katsayılar }\end{array}$ & $\mathbf{t}$ & $\begin{array}{c}\text { Anlam } \\
\text { Düzeyi }\end{array}$ & Tolerans & V.I.F. \\
\cline { 2 - 6 } & B & Std. Hata & Beta & & & \\
\hline (Sabit) & 1,174 &, 173 & & 6,777 &, 000 & & 1,000 \\
\hline İş Stresi &, 334 &, 055 &, 275 & 6,044 &, 000 & 1,000 & 1,000 \\
\hline \multicolumn{7}{|c|}{ Bağımlı Değişken: Sabote Edici Davranışlar } \\
\hline \multicolumn{7}{|c|}{$\mathrm{R}: 0,275 ; \mathrm{R}^{2}: 0,076 ;$ Düzeltilmiş $\mathrm{R}^{2}: 0,073 ;$ Model için F:36,532 ; $\mathrm{p}=0,000 ;$ s.d.: 1; D-W:1,006 } \\
\hline
\end{tabular}

Yapılan basit doğrusal regresyon analizi sonuçları incelendiğinde modelin anlamlı $(F=36,532 ; p<0,05)$ olduğu görülmektedir. Varyans şişme değeri olarak adlandırılan VIF değeri 1,000 olarak bulgulanmıştır ve çoklu bağlantı sorunu olmadığı $(\mathrm{VIF}<10)$ söylenebilir. Oto korelasyona işaret eden $\mathrm{D}-\mathrm{W}$ değeri 1,006 olarak bulgulanmıştır. Bu bulgu oto korelasyon olmadığının göstergesidir. Regresyon katsayılarının anlamlılığına işaret eden $t$ istatistiği $(t=6,044 ; p<0,05)$ anlamlıdır.

İş stresi ile sabote edici davranışlar arasındaki ilişkinin, istatistiksel olarak anlamlı $(p<0,05)$ olduğu söylenebilir. Değişkenler arasında pozitif yönlü bir ilişki $(R=0,275)$ vardır. Bağımsız değişkenin bağımlı değişkeni açıklama oranı olan $R^{2}$ değeri 0,076 olarak hesaplanmıştır. Bu sonuç, sabote edici davranışlardaki değişimlerin \%o76,0'ının, iş stresi ile açıklandığını göstermektedir. İş stresindeki 1 birimlik artış, sabote edici davranışları 0,275 birim artırmaktadır. Elde edilen verilere 
ilişkin basit doğrusal regresyon modeli; $a=1,174$ ve $b=0,275$ olmak üzere $Y=a+b X$ ise $Y=1,174+0,275 X$ olarak kurulabilir.

\subsection{4. İş Stresi ile Mahçup Edici Davranışlar Arasındaki Regresyonel İlişkiye Yönelik Bulgular}

İş stresi bağımsız, mahçup edici davranışlar bağımlı değişken olmak üzere değişkenler arasındaki doğrusal ilişkileri test etmek, mahçup edici davranışlardaki değişimin ne kadarının iş stresi tarafından açıklanabildiğini araştırmak ve değişkenler arasındaki ilişkiyi matematiksel olarak ifade etmek amacıyla çoklu doğrusal regresyon analizi yapılmıştır. Analiz sonucunda elde edilen bulgular Tablo 10'da özetlenmektedir.

Tablo 10: İş Stresinin Mahçup Edici Davranışlara Etkisi

\begin{tabular}{|c|c|c|c|c|c|c|c|}
\hline \multirow[b]{2}{*}{ Model } & \multicolumn{2}{|c|}{$\begin{array}{c}\text { Standardize Edilmemiş } \\
\text { Katsayılar }\end{array}$} & \multirow{2}{*}{$\begin{array}{c}\begin{array}{c}\text { Standardize } \\
\text { Katsayılar }\end{array} \\
\text { Beta }\end{array}$} & \multirow[t]{2}{*}{$\mathbf{t}$} & \multirow{2}{*}{$\begin{array}{l}\text { Anlam } \\
\text { Düzeyi }\end{array}$} & \multirow[t]{2}{*}{ Tolerans } & \multirow[t]{2}{*}{ V.I.F } \\
\hline & B & Std. Hata & & & & & \\
\hline (Sabit) & 2,308 & ,195 & & 11,833 &, 000 & & \\
\hline İş Stresi & ,115 & ,062 & ,087 & 1,848 & ,065 & 1,000 & 1,000 \\
\hline \multicolumn{8}{|c|}{ Bağımlı Değişken: Mahçup Edici Davranışlar } \\
\hline \multicolumn{8}{|c|}{$R: 0,087$; $R^{2}: 0,008$; Düzeltilmiş $R^{2}: 0,005$; Model için F:3,415; $p=0,065 ;$ s.d.: 1; D-W:1,477 } \\
\hline
\end{tabular}

İş stresi ile mahçup edici davranışlar arasında yapılan regresyon analizi sonucunda iki değişken arasında istatistiksel olarak anlamlı bir ilişki bulunamamıştır $(R=0,087 ; p>, 001)$.

\section{Sonuç ve Öneriler}

Aşçıların iş stres düzeyleri ile toksik davranış düzeyleri arasında pozitif yönlü ve anlamlı bir ilişki vardır. Dolayısıyla iş stres düzeyinin artması veya azalması toksik davranış algısını da aynı yönde artıracak veya azaltacaktır denilebilir. Bu bulgu iş stres seviyesinin artmasının aşçıların olumsuz duygular beslemesine, işe ve işletmeye tepkisel yaklaşımına yol açarak, toksik davranışlarını artırdığı şeklinde yorumlanabilir. Günümüz işletmelerinde stres, depresyon, tükenmişlik gibi hisler, temel insani duyguların suistimal edilmesinden ve agresif davranışlardan beslenmektedir. Kırbaç (2013:34) çalışmasında doyumsuzluk ve stresin yüksek seviyelerde seyretmesinin toksik davranış algısını artırdığını ifade etmiştir.

Aşçıların örgütsel politikalardan kaynaklanan stres düzeyleri ile toksik davranış düzeyleri arasında pozitif yönlü ve anlamlı bir ilişki vardır. Dolayısıyla örgütsel politikalardan kaynaklanan stres düzeyinin artması veya azalması toksik davranış algısını da aynı yönde artıracak veya azaltacaktır denilebilir. İşletmedeki kötü yönetim yapısı ve yönetim tarzı aşçılarda hem stres oluşumunda hem de toksik davranışların ortaya çıkmasında etken olabilir. Otokratik bir anlayışla yönetilen iş yerlerinde, özellikle tepeye doğru yükselen güç kullanımı, aşçıların ve diğer çalışanların stres içinde olmalarına yol açabilir. Cezanın kullanımı, aşçılarda gerilim oluşturabilir. Sınırlı kaynaklar ve sınırlı ödüller için çalışanları yarıştırmak stres yaratabilir. Bu duygular aşçıların olumsuz duygular beslemesine, işe ve işletmelerine karşı tepkisel yaklaşımına neden olabilir. Ayrıca stres ve toksik davranışların aşçılarda yüksek seviyelerde hissedilmesi tükenmişliğe yol açabilmektedir. İşletme içinde adil olmayan başarı değerlendirmelerine göre yapılan terfiler kişiler arasında bir çatışmaya dolayısıyla da strese neden olabilmektedir. Yöneticilerin işletme içinde kendileriyle olan 
ilişkileri olumlu olan kişileri bilgi, beceri ve kıdemleri yetersiz olmasına rağmen bir üst kadroya terfi ettirmeleri, çalışanlar arasında hem yöneticiye karşı hem de bu kadroya gelen kişiye karşı olumsuz duygular beslenmesine ve çalışanlar arasında çatışma üzerine kurulu davranışların ortaya çıkmasına sebep olabilmektedir.

Aşçıların örgütsel yapıdan kaynaklanan stres düzeyleri ile toksik davranış düzeyleri arasında pozitif yönlü ve anlamlı bir ilişki vardır. Dolayısıyla örgütsel yapıdan kaynaklanan stres düzeyinin artması veya azalması toksik davranış algısını da aynı yönde artıracak veya azaltacaktır denilebilir. Mutfak departmanında hemen hemen her iş, potansiyel birer stres kaynağı olabilmektedir. Zaman sınırlamaları, yetki yetersizliği, işin niteliği, kararsızlık, ücret yetersizliği aşçıları etkileyen en önemli stres kaynaklarıdır. Özellikle alınan ücretin azlığı aşçıları yıpratıp, hayat standartlarını ayarlamaları konusunda kaygı ve strese sebebiyet verebilir ve toksik davranışları daha belirgin hale getirebilir. Ücret artışının adil olmaması, hak ettiğini düşündüğü primi alamaması, cezanın herkese uygulandığı gibi uygulanmaması, hak etmeyene ödül verilmesi gibi nedenler adaletsizlik algısı yaratabilecektir. Adaletsizlik algısı ise işletmelerde sabotaj nedeni olabilmektedir. Birey maruz kaldığını düşündüğü adaletsiz uygulamaları protesto etmek için, düzeltmek için veya ispat etmek için sabote edici davranışlara başvurabilir. Örneğin; gerekli evrakları yok edebilir veya bilgi saklayabilir.

Aşçıların iş ortamındaki fiziksel şartlardan kaynaklanan stres düzeyleri ile toksik davranış düzeyleri arasında pozitif yönlü ve anlamlı bir ilişki vardır. Dolayısıyla iş ortamındaki fiziksel şartlardan kaynaklanan stres düzeyinin artması veya azalması toksik davranış algısını da aynı yönde artıracak veya azaltacaktır denilebilir. Bu bulguyu destekler nitelikte Hauge, Skogstad ve Einarsen (2007: 220-242) stres yaratan işyeri koşullarının ve yıkıcı liderliğin, astların birbirine uyguladığı olumsuz davranışları ve işyeri zorbalığını arttırdığını bulgulamışlardır. Özdevecioğlu ve Aksoy (2005:97) yüksek nem oranı, yüksek ısı, soğuk hava koşulları, yetersiz ışıklandırma, kirli hava veya çok pis kokulu ortamların bireylerin saldırganlaşmasına neden olabileceğini bulgulamışlardır. Mutfağın teknik ve işlevsellik açısından tam anlamıyla donatılmış ve yerleştirilmiş olması gerekmektedir. Mutfak ancak verimli çalışılacak ortamların mevcut olması ve teknik donanımının sağlanması ile ve nitelikli personelin çalışması ile başarıya ulaşabilir. Mutfaklarda görev yapan aşçıların çalışma ortamı, mutfağın özelliği gereği sıcak, nemli ve kapalıdır. Üretimin önemli bir bölümü ön hazırlık olarak yemeğin sunulacağı zamandan önce yapılır. Üretim, uzun süre ayakta kalmayı gerektirdiği için mutfak çalışanlarında, varis ve bel ağrıları, mantar, egzama, taban çökmesi, yıpranma, sıcak-soğuk farkından dolayı baş ağrıları, kalp-damar hastalıkları, saç dökülmesi ve strese bağlı hastalık riskleri söz konusu olabilmektedir. Zaten var olan olumsuz fiziksel koşulların daha da kötü hale getirilmesi çalışan aşçıların toksik bir kimliğe bürünmelerine sebebiyet verebilir. Bu durum aşçıların işletmelerde olumsuz fiziksel şartların getirmiş olduğu stresle beraber umutsuzluk, öfke, düşük moral, zayıf iletişim, depresyon gibi olumsuz duyguları harekete geçirerek çalışanlar arasında stresli, gergin bir ortam oluşturmaya çalışabilecekleri şeklinde yorumlanabilir. Ayrıca fiziksel şartlar hakkında aşçıların beklentilerini de araştırmak soruna çözüm odaklı olumlu sonuçlar doğurabilir.

Aşçıların işin yapısı ile ilgili stres düzeyleri ile toksik davranış düzeyleri arasında pozitif yönlü ve anlamlı bir ilişki vardır. Dolayısıyla işin yapısı ile ilgili stres düzeyinin artması veya azalması toksik davranış algısını da aynı yönde artıracak veya azaltacaktır denilebilir. İş ortamı ve yapılan iş aşçıları rahatsız edici strese maruz bırakabilir ve aşçıların olumsuz tutum ve iş davranışlarında bulunmasına neden olabilir. Gerginlik ve kaygı duygusunu aşamayan kişi için diğer gün işe gitmek çok zor gelebilmektedir. Dolayısıyla işe gitmeme, işyerine geç gelme, işe devamsızlık, işten 
ayrılma gibi hem çalışan hem de işletme açısından olumsuz tutum ve davranışlar ortaya çıkabilmektedir. Aşçı işin yapısından kaynaklanan stres faktörlerini daha fazla yönetebilecek gücü kendisinde bulamadığında ya çalışmakta olduğu işletmeyi terk edecek ya da ruhsal çöküntüye girip toksik davranış eğilimi gösterecektir. Duygusal yönden kendini yıpranmış hisseden aşçı ise çalışma arkadaşlarına karşı olumsuz tutum içerisinde olmasına paralel işine karşı da bir tatminsizlik yaşayabilecektir.

Aşçıların kişilerarası ilişkilerden kaynaklanan stres düzeyleri ile toksik davranış düzeyleri arasında pozitif yönlü ve anlamlı bir ilişki vardır. Dolayısıyla kişilerarası ilişkilerden kaynaklanan stres düzeyinin artması veya azalması toksik davranış algısını da aynı yönde artıracak veya azaltacaktır denilebilir. Bu bulguyu aşırı rekabetçi ortam, yetersiz destek, hak edilen ilgiden yoksunluk gibi tutumların aşçılarda düşmanca ve asabi eylemleri ve stres uyandıran durumlardaki riskleri de arttırarak daha fazla öfke ile davranmalarına, daha fazla kaygı, düşük öz saygı ve depresif belirtiler yaşamalarına yol açabilir şeklinde ifade edilebilir. Ayrıca kişilerarası ilişkilerde yaşanan öfkenin içselleştirilmesinin ve intikam tepkileri şeklinde yaşanmasının, gizlenen öfkenin davranışlara döküldüğü zaman daha fazla saldırgan davranışlara yol açacağı için bu durumun aşçıların fiziksel ve zihinsel sağlığı için işlevsel olmadığı söylenebilir. Bunlara ek olarak işletme içerisinde dedikodu/söylenti biçiminde aktarılan bilgilerin doğru olsa da güvenin azalmasına, yanlış anlamalara, belirsizliğin ve endişenin artmasına neden olabileceği bu durumun da işletme içinde aşçılarda iş tatminsizliği, stresin artması, düşük düzeyde performans $\mathrm{vb}$. kurumsal başarısızlık işaretlerine sebebiyet verebileceği iddia edilebilir. Aşçılar, çatışma nedeniyle zamanlarını ve enerjilerini gerçekleştirilmesi gerekli amaçların dışındaki konulara harcayabilirler. Böyle bir durumda ise stres seviyesi yükselebilir, aşçılar arasında sıkıntı ve ilgisizlik oluşabilir, aşçıların performansları düşerek; öfke patlamaları ve çirkin davranış modelleri ortaya çıkabilir. Sağlıksız iş ilişkileri yüzünden hasta olan çalışanlar vardır. Yetersiz iliş̧ilerin olduğu işletmelerde, iş tatminsizliği, işle bağıntılı kuşkular, güvensizlikler artabilir ve toksik davranışlar belirgin hale gelebilir. Çalışanların bazılarında, yeni işe alınan kişilere karşı, yardımcı olmak yerine "eğer işi öğrenirse benim yerime geçer" ya da "işi benden daha iyi yapabilir" gibi endişelerle yardımcı olmamak gibi bir anlayış vardır. Bu gibi davranışlara maruz kalan yeni işgörenin işe uyumu ve ilişkileri olumsuz olabilmektedir. Çalışan, "beni burada istemiyorlar, yalnız kalacağım" düşüncesiyle strese girebilmektedir.

Aşçıların bireysel stres düzeyleri ile toksik davranış düzeyleri arasında pozitif yönlü ve anlamlı bir ilişki vardır. Dolayısıyla bireysel stres düzeyinin artması veya azalması toksik davranış algısını da aynı yönde artıracak veya azaltacaktır denilebilir. Aşçıların diğer çalışanlar hakkındaki olumsuz düşünceleri, özel yaşamlarındaki sıkıntılar, anlayışsızlık, tükenmişlik sendromuna neden olabilir. Etrafına olumsuz gözlerle bakan bir aşçı, arkadaşlarının ve diğer insanların değerini takdir etmede yetersiz kalarak, kapasiteleri hakkında olumsuz düşünceler geliştirebilir. Ya da aşçılarda iş stresinin artması, mesleğin doğası gereği yaşanan stresle başa çıkamamaları sonucu fizyolojik ve duygusal anlamda kendilerini tükenmiş hissetme ve toksik davranış gösterme eğilimlerini ortaya çıkarabilmektedir. Ayrıca bireyin kişilik yapısının düşmanca davranışlar gösterme eğiliminde olması yani kindar olması ve bazı psikolojik rahatsızlıklar bireyleri saldırgan davranışlara sevk edebilir.

Aşçıların iş stres düzeyleri ile sabote edici davranış düzeyleri arasında pozitif yönlü ve anlamlı bir ilişki vardır. Dolayısıyla iş stres düzeyinin artması veya azalması sabote edici davranış algısını da aynı yönde artıracak veya azaltacaktır denilebilir. Bu bulgu sabote edici davranışların, aşçıların işlerini ve çalıştıkları kurumu olumsuz değerlendirmelerine neden olabileceği, motivasyonu, memnuniyeti ve bağlılık 
seviyesini azaltabileceği, iş-aile çatışmasına zemin hazırlayabileceği, duygusallık ve stres kaynaklı sorunları arttırabileceği, performansı olumsuz yönde etkileyebileceği, üretkenliğe zarar veren işyeri davranışlarını tetikleyebileceği şeklinde yorumlanabilir. Nedeni ne olursa olsun, sapkın davranışların ve toksik davranışların örgütsel yaşamın kalitesini, bireylerin motivasyonunu, moralini, örgütsel bağlılığını ve iş tatminini olumsuz yönde etkileyebileceği göz ardı edilmemelidir.

Aşçıların iş stres düzeyleri ile mahçup edici davranış düzeyleri arasında yapılan korelasyon analizi sonucunda iki değişken arasında istatistiksel olarak anlamlı bir ilişki bulunamamıştır.

Son olarak elde edilen bulgularla şu sonuca varılabilir; konaklama işletmelerinin emek yoğun olması ve müşteri ile direkt temas gerektirmesi sektörde insan faktörünü ön plana çıkarmaktadır. Öte yandan, işgücü verimliliği ve müşteri memnuniyetinin sağlanmasında aşçıların fiziksel ve psikolojik sağlığı büyük önem taşımaktadır. Bunun için konaklama işletmelerinde, aşçıların rahat, stresten uzak olabilecekleri bir ortamın yaratılması gerekmektedir. Bu çalışmada da otel işletmelerinde çalışan aşçıların iş stres düzeyi ile toksik davranışları arasındaki ilişki değerlendirilmiştir. Yapılan değerlendirmeler sonucunda, iş stresi ile toksik davranışlar arasında anlamlı ilişkiler tespit edilmiştir.

Araştırma sonuçlarından da anlaşıldığı üzere; otel işletmelerinde aşçıların karşılanmayan her ihtiyacı birer stres kaynağıdır. Etkilenilen stres kaynağı her ne olursa olsun, olumsuz stres kaynaklarının olumlu hale dönüştürülmesi ve otel işletmesinde yeterince çekici bir ortam sağlayarak toksik davranışların minimize edilmesi gerekmektedir. Otel işletmelerinde çalışan aşçıların iş stresleri işgücü verimliliğini ve müşteri memnuniyetini doğrudan etkilediğinden, üst yönetimin çalışanlarını çok iyi tanıyıp hangi koşulların strese neden olduğunu öğrenmesi ve stresle başa çıkmada etkili yöntemleri uygulaması olumlu sonuçlar doğurabilecektir. Akılcı çözümler üreten ve uygulamaya koyan işletmeler hem aşçıların sağlıklı olmalarını sağlamış olacak, hem de yüksek maliyetlerden kurtulmuş olacaklardır. Tüm bunların neticesinde fiziksel, ruhsal ve psikolojik olarak rahat, sağlıklı çalışma imkânı elde eden aşçılar, yaptıkları işten doyum hissedecek ve daha fazla motive olarak performansları yükselecektir. Nitelikli işgücü ile etkililik ve verimlilik anlayışını benimsemiş işletmelerin ayakta kalabileceği düşünüldüğünde işletmelerin başarıya ulaşabilmek için, müşteriden önce çalışan memnuniyetine önem vermesi gerekmektedir. İşören memnuniyeti müşteri memnuniyetine de olumlu anlamda ve ciddi oranda katkıda bulunacaktır. İşletmeler, aşçılarda stres oluşturan durumları belirleyip, bunların stres oluşturmaması için önlemler alır ve işyerinde yaşanan stres düzeyinde bir denge sağlayabilirlerse, aşçıların toksik davranışlarında olumlu değişimler gözlemlenebilecektir. Ayrıca iş stresi ve bileşenlerinin toksik davranışlar ve bileşenleri ile ilişkilerinin test edildiği bu araştırma sonuçlarının farklı araştırmacılar tarafından dört yıldız ve altı otellerde yapılacak çalışmalarla tekrarlanması, değişkenler arasındaki ilişkilere dair bulguların güvenirliği açısından önem arz etmektedir. İş stresi ve bileşenleri ile toksik davranışlar ve bileşenleri arasındaki anlamlı ilişkilere işaret eden bulgular, daha önce araştırılmamış olmaları dolayısıyla, literatüre katkı sağlama potansiyeline sahiptir. İs stresinin alt bileşenlerinden hangisinin hangi toksik davranış alt faktörünü neden daha çok veya daha az etkilediğinin araştırılması farklı bir çalışmanın konusu olabilir. İş stresinin toksik davranış bileşenlerinden mahçup edici davranışlar ile istatistiksel olarak anlamlı ilişkiler göstermemiş olması da bunun nedenlerinin araştırılabileceği farklı çalışma konularına işaret etmesi açısından önemli görülmektedir. 


\section{Kaynakça}

Adıgüzel, O. (2012). İşle ilgili stres, rol çatışması ve rol belirsizliğinin beklenen personel devri üzerine etkisi: Hemşireler üzerinde bir uygulama. Uluslararası Alanya Işletme Fakültesi Dergisi. 4 (3), 163-169.

Akova, O. ve Işık, K. (2008). Otel işletmelerinde stres yönetimi: İstanbul'daki beş yıldızı otel işletmelerinde bir araştırma. Kocaeli Üniversitesi Sosyal Bilimler Enstitüsü Dergisi, 15, 17-44.

Allison, D. G. (1997). Coping with stress in the principalship. Journal of Educational Administration, 35 (1), 39-55.

Altunışık, R., Coşkun, R., Bayraktaroğlu, S. ve Yıldırım, E. (2005). Sosyal Bilimlerde araştırma yöntemleri SPSS uygulamalı, Sakarya: Sakarya Yayıncılık.

Appelbaum, S. H., laconi, G. D. ve Matousek, A. (2007). 'Positive and negative deviant workplace behaviors: Causes, impacts and solutions.' Corporate Governance, 7(5), 586-598.

Appelbaum, S. H. ve Roy-Girard, D. (2007). 'Toxins in the workplace: Affecton organizations and employees' Corporate Governance, 7(1), 17-28. doi:10.1108/14720700710727087.

Appelbaum, S. H. ve Shapiro, B. T. (2006). 'Diagnosis and remedies for deviant workplace behaviors' The Journal of American Academy of Business, Cambridge 9 (2), 14-20.

Ataklı, A. (1999), Öğretmenlerde stres ve iş memnuniyeti, Çağdaş Eğitim dergisi, 256, 7-13.

Avcı, Ö. (2007), Örgütsel stres kaynaklarının halkla ilişkiler açısından incelenmesi, Yayımlanmamış Yüksek Lisans Tezi, Gazi Üniversitesi, Ankara.

Bauer, G. (2008). 'Warning' Working Well, 13-16.

Birdir, K. ve Kılıçhan, R. (2013). "Mutfak şeflerinin mesleki eğitim düzeyleri ve yaşadıkları eğitim problemlerinin tespitine yönelik bir çalışma." 14. ulusal turizm kongresi, Erciyes Üniversitesi, 05-08 Aralık 2013, ss.615-635.

Bloisi, W. ve Hoel, H. (2008). 'Abusive work practices and bullying among chefs: A review of the literature' International Journal of Hospitality Management 27, 649656.

Borş, D. (2010). Konaklama işletmelerinde stresin çalışan performansına etkileri: Belek'teki beş yıldızlı otel işletmelerinde bir uygulama, Yayımlanmamış Yüksek Lisans Tezi, Akdeniz Üniversitesi, Antalya.

Campbell, I. (1995). Stress litigation and training. Management Development Review, 8 (4), 21-22.

Chapman, D. (2009). 'Identifying a toxic workplace' http://kickbully.com/toxic.html (29.09.2013).

Cho, J. J., Kim, J. Y., Chang, S. J., Fiedler, N., Koh, S. B., Crabtree, B. F., Kang, D. M., Kim, Y. K. ve Choi, Y. H. (2008). 'Occupational stress and depression in Korean employees' Int Arch Occup Environ Health, 82, 47-57.

Erdoğan, T., Ünsar, S. A. ve Süt, N. (2009). Stresin çalışanlar üzerindeki etkileri: bir araştırma. Süleyman Demirel Üniversitesi, Iktisadi ve Idari Bilimler Fakültesi Dergisi, 14 (2), 447-461.

Ergül, A. (2012). Çalışma yaşamında stresin bireysel performans üzerindeki etkileri: Eğitim ve sağlık çalışanlarına yönelik bir araştırma. Balıkesir Üniversitesi Sosyal Bilimler Enstitüsü İşletme Anabilim Dalı. Yayımlanmamış Yüksek Lisans Tezi.

Erkutlu, H., Chafra, J. ve Bumin, B. (2011). Organizational culture's role in the relationship between power bases and job stress. Hacettepe Üniversitesi Eğitim Fakültesi Dergisi (H. U. Journal of Education), 40, 198-209.

Frederick, C. (2009). 'Toxic employees' Motor Age, 62-66. 
Gignac, A. ve Appelbaum, S. H. (1997). 'The impact of stress on customer service representatives: A comparative study' Journal of Workplace Learning, 9 (1), 2033.

Gilbert, J. A., Ruffino, N. C., Ivancevich, J. M. ve Konopaske, R. (2012). 'Toxic versus cooperative behaviors at work: The role of organizational culture and leadership in creating community-centered organizations' International Journal of Leadership Studies, 7 (1), 29-47.

Gül, H., Oktay, E. ve Gökçe, H. (2008). İş tatmini, stres, örgütsel bağlılık, işten ayrılma niyeti ve performans arasındaki ilişkiler: Sağlık sektöründe bir uygulama. Akademik Bakış, (15), 1-11.

Güney, S. (2007). Yönetim ve organizasyon. (2. Baskı). S. Güney (Ed.), Örgütsel bağlılık içinde (s.233-257). Ankara: Nobel Yayıncılık.

Hauge, L. J., Skogstad, A. ve Einarsen, S. (2007). 'Relationships between stressful work environments and bullying: Results of a large representative study' Work \& Stress, 21(3), 220-242.

Hız, G., Karataş, A. Ve Uluksar F.Ö., (2015). Konaklama işletmelerinde mutfakta istihdam edilenlerin tükenmişlik sendromu: Marmaris örneği, Ekonomi ve Yönetim Araştırmaları Dergisi, 4(2), 8-29.

Holloway, E. L. ve Kusy, M. E. (2010). 'Disruptive and toxic behaviors inhealthcare: Zero tolerance, the bottom line and what to do about it' Medical Practice Management, 335-340.

Ismail, A., Yao, A. ve Yunus, N. K. Y. (2009). Relationship between occupational stressand job satisfaction: An empirical study in Malaysia. The Romanian Economic Journal, 4, 3-29.

Kalaycı, Ş. (2009). SPSS uygulamalı çok değişkenli istatistik teknikleri. (4. Baskı). Ankara: Asil Yayın.

Kara, D. (2009). 'Eğitim-öğretim yaşantısında stres yaratan faktörler ve aile özelliklerine göre öğrencilerin stresle başa çıkma davranışlarının incelenmesi' Selçuk Üniversitesi Sosyal Bilimler Enstitüsü Dergisi, 22, 255-263.

Karasar, N. (2008). Bilimsel araştırma yöntemi. (18. Baskı). Ankara: Nobel Yayınları.

Karimi, R. ve Alipour, F. (2011). Reduce job stress in organizations: Role of locus of control. International Journal of Business and Social Science, 2 (18), 232-236.

Kırbaç, M. (2013). Eğitim Örgütlerinde Toksik Liderlik, Yayımlanmamış Doktora Tezi, İnönü Üniversitesi, Malatya.

Kimlinger, D. C., Mines, R. A., Kent, M. S., Hull, S., Hiester, P. ve Moore, Y. (2011). 'Psychology of performance: Toxicity in the workplace' Bizpsyc Executive Coaching Series, 1-6.

Kusy, M. E. ve Holloway, E. L. (2009). Toxic workplace! Managing toxic personalities and their systems of power, San Francisco, CA: Jossey-Bass.

Lubit, R. (2004). 'The tyranny of toxic managers: Applying emotional intelligence to deal with difficult personalities' Ivey Business Journal, 1-7.

Maitlis, S. ve Özçelik, H. (2004). 'Toxic decision processes: A study of emotionand organizational decision making' Organization Science, 15 (4), 375-393.

Malik, N. (2011). A study on occupational stress experienced by private and public banks employees in Quetta city. African Journal of Business Management, 5 (8), 3063-3070.

Mavili Aktaş, A., (2001) Bir kamu kuruluşunun üst düzey yöneticilerinin iş stresi ve kişilik özellikleri", Ankara Üniversitesi Siyasal Bilgiler Fakültesi Dergisi, 26-42,

Mines, R. A., Meyer, R. A. ve Mines, M. R. (2004). 'Emotional intelligence and emotional toxicity: Implications for attorneys and law firms' The Colorado Lawyer, 33 (4), 91-96. 
Moncrief, W. C., Babakus, E., Cravens, D. W. ve Johnston, M. (1997). Examining the antecedents and consequences of salesperson job stress. European Journal of Marketing, 31 (11-12), 786-798.

Nakip, M. (2006). Pazarlama araştırmaları teknikler ve SPSS destekli uygulamalar. (Genişletilmiş 2. Basım). Ankara: Seçkin Yayıncılık.

Özdevecioğlu, M. ve Aksoy, M. S. (2005). 'Organizasyonlarda sabotaj: Türleri, amaçları, hedefleri ve yönetimi' Cumhuriyet Üniversitesi Iktisadi ve Idari Bilimler Dergisi, 6 (1), 95-109.

Özdevecioğlu, M., Bulut, E. A., Çirli Y., Gemici, T., Tozal, M. ve Doğan, Y.(2003). 'Kadın ve erkek yöneticilerin yönetimi altındaki personelin motivasyon, stres ve iş tatmini farklılıklarını belirlemeye yönelik bir araştırma' Yönetim ve Ekonomi Dergisi, 10 (2), 125-138.

Özer, M. A. (2012). Çalışanlar için verimlilik anahtarı: Stres yönetimi. TÜHis İş Hukuku ve İktisat Dergisi, 24 (1-2), 45-66.

Özkaya, O. M., Yakın, V. ve Ekinci, T. (2008). Stres düzeylerinin çalışanların iş doyumu üzerine etkisi: Celal Bayar Üniversitesi çalışanları üzerine ampirik bir araştırma. Yönetim ve Ekonomi Dergisi, 15 (1), 163-179.

Pelletier, K. L. (2010). 'Leader toxicity: An empirical investigation of toxic behavior and rhetoric'. Leadership, 6 (4), 373-389.

Rosch, P. J. ve Kenneth, R. P. (1987). 'Designing worksite stress Management programs. In Stress Management in Work Settings' L. R. Murphy ve R. G. Schoenborn. (Eds). Washington, DC: National Institute for Occupational Safety and Health.

Sadri, G. ve Marcoulides, G. A. (1997). 'An examination of academic and occupational stress in the USA' International Journal of Educational Management, 11 (1), 3243.

Saldamlı, A. (2000). 'Otel işletmelerinde stres kaynakları ve çalışanlar üzerindeki etkileri: Beş yıldızlı otellerde bir uygulama' Çukurova Üniversitesi Sosyal Bilimler Dergisi, 6 (6), 288-302.

Sarışık, M. (2008). Turizm işletmelerinde çağdaş yönetim teknikleri. Okumuş, F. ve Avcı, U. (Ed.), 'Turizm işletmelerinde stres yönetimi' içinde (ss. 149-174). Ankara: Detay Yayıncılık.

Schaubroeck, J., Walumbwa, F. O., Ganster, D. C. \& Kepes, S. (2007). Destructive leader traits and the neutralizing influence of an "enriched" job. The Leadership Quarterly, 18, 236-251.

Scholten, A. (2016). '10 signs that your workplace is toxic and what you should do abouth it,' http://www.innermedpublishing.com/toxic\%20workplace.html, erişim tarihi: 24-04-2016.

Serinkan, C., Kaymakçı, K., Alişan, U. ve Avcık, C. (2012). Kamu sektöründe örgütsel stres ve kariyer: Denizli'de yapılan bir araştırma. Organizasyon ve Yönetim Bilimleri Dergisi, 4 (1), 21-32.

Singh, R. K. (2008). 'Toxic bosses and stress' The Indian Police Journal, 1, 3842.

Snyder, J. (2010). 'Is workplace stress toxic to your system?' The Healthcare Ledger, 18-22.

Soysal, A. (2009). Farklı sektörlerde çalışan işgörenlerde örgütsel stres kaynakları: Kahramanmaraş ve Gaziantep'te bir araştırma. Süleyman Demirel Üniversitesi Íktisadi ve Idari Bilimler Fakültesi Dergisi, 14 (2), 333-359.

Şener, B. (2001). Modern otel işletmelerinde yönetim ve organizasyon. (3. Baskı). Ankara: Detay Yayıncılık.

Tekin, M. ve Çiçek, E. (2005, Kasım). 'İşletmelerde rekabet üstünlüğü sağlamada farklı bir yaklaşım: Değer temelli pazarlama' $V$. ulusal üretim araştırmaları sempozyumu bildiriler kitabı içinde (ss.63-68). V. Ulusal Üretim Araştırmaları Sempozyumu, İstanbul. 
Tepper, B. J. (2007). 'Abusive supervision in work organizations: Review, synthesis, and research agenda.' Journal of Management, 33(3), 261-289, doi: $10.1177 / 0149206307300812$.

Tiritoğlu, E. (2006). Konaklama işletmelerinde stres faktörlerinin işgören devir hızına etkisi üzerine bir alan araştırması, Yayımlanmamış Yüksek Lisans Tezi, Sakarya Üniversitesi, Sakarya.

Toker, B. (2007). 'Demografik değişkenlerin iş tatminine etkileri: İzmir'deki beş ve dört yıldızlı otellere yönelik bir uygulama' Doğuş Üniversitesi Dergisi, 8 (1), 92-107.

Tokmak, C., Kaplan, Ç. ve Türkmen, F. (2011). İş koşullarının sağlık çalışanlarında yol açtığı stres üzerine Sivas'ta bir araştırma. İşletme Araştırmaları Dergisi, 3 (1), 49-68.

Töremen, F. ve Çankaya, İ. (2008). 'Yönetimde etkili bir yaklaşım: Duygu yönetimi' Kuramsal Eğitimbilim, 1 (1), 33-47.

Türk, K., Eroğlu, C. ve Türk, D. (2008). T.C. Devlet hastanelerindeki çalışma koşullarının stres üzerine etkilerini ölçmeye yönelik bir araştırma. Uluslararası Insan Bilimleri Dergisi, 5 (1), 1-17.

Unur, K. (2011). İşletmecilikte güncel konular. T. T. Turaboğlu (Ed.), Stres ve yönetimi içinde (s.233-273). Bursa: Ekin Basım Yayın Dağıtım.

Üngüren, E., Doğan, H., Özmen, M. ve Tekin, Ö. A. (2010). 'Otel çalışanlarının tükenmişlik ve iş tatmin düzeyleri ilişkisi' Journal of Yaşar University, 17 (5), 2922-2937.

Voorhees, TJ. V. (2011). 'Toxic employees: A guide to managing/firing difficult employees' Pacific Crest Group, 1-31.

Weber, J. (2011). 'Toxic co-workers, bullies and you dealing with them without becoming one of them' 26 Mayı 2013 tarihinde http://www.Igma.ca/assets/Programs and Events/Clerks Forum/2011 Clerks Forum/Jim-Webber-toxic-coworkers-and-bullies.pdf adresinden alınmıştır.

Yıldırım, O., Tektüfekçi, F. ve Çukacı, Y. C. (2004). Modern toplum hastalığı: Stres ve muhasebe meslek elemanı üzerindeki etkileri. Süleyman Demirel Üniversitesi Iktisadi ve Idari Bilimler Fakültesi Dergisi, 9 (2), 1-20.

Ziauddin, Khan, M. R., Jam, F. A. ve Hijazi, S. T. (2010). 'The impacts of employees job stress on organizational commitment' European Journal of Social Sciences, $13(4), 617-622$. 